Prepared in cooperation with the Central Platte Natural Resources District, the Nebraska Department of Natural Resources, and the Nebraska Environmental Trust

\title{
Comparison of Water Consumption in Two Riparian Vegetation Communities along the Central Platte River, Nebraska, 2008-09 and 2011
}

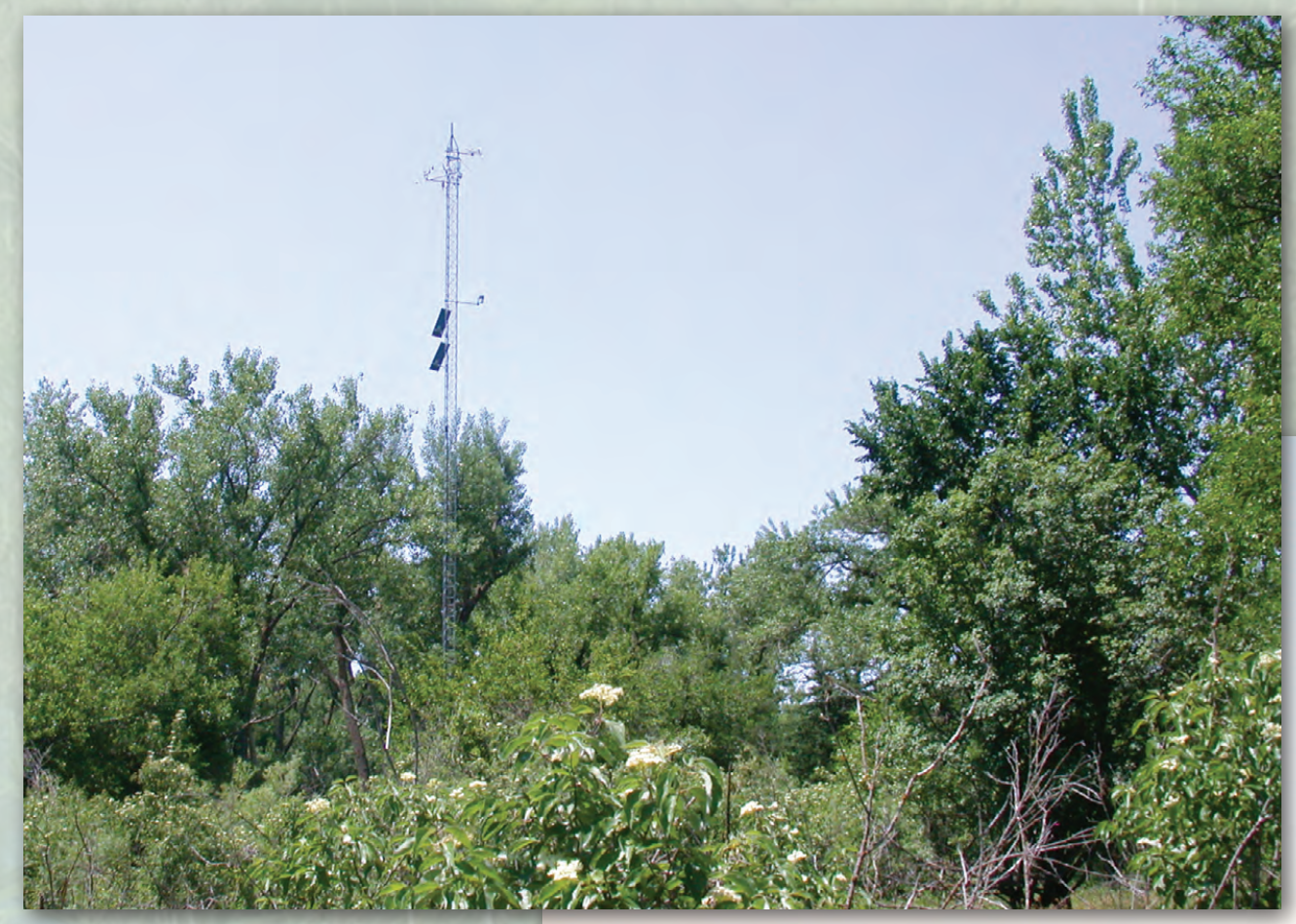

Scientific Investigations Report 2013-5203 




Cover. Meteorological instrumentation mounted on towers at $A$, a riparian woodland site; and $B$, a riparian grassland site. Photographs by David Rus, U.S. Geological Survey. 


\section{Comparison of Water Consumption in Two Riparian Vegetation Communities along the Central Platte River, Nebraska, 2008-09 and 2011}

By Brent M. Hall and David L. Rus

Prepared in cooperation with the Central Platte Natural Resources District, the Nebraska Department of Natural Resources, and the Nebraska Environmental Trust

Scientific Investigations Report 2013-5203 


\title{
U.S. Department of the Interior SALLY JEWELL, Secretary
}

\section{U.S. Geological Survey Suzette M. Kimball, Acting Director}

\author{
U.S. Geological Survey, Reston, Virginia: 2013
}

For more information on the USGS - the Federal source for science about the Earth, its natural and living resources, natural hazards, and the environment, visit http://www.usgs.gov or call 1-888-ASK-USGS.

For an overview of USGS information products, including maps, imagery, and publications, visit http://www.usgs.gov/pubprod

To order this and other USGS information products, visit http://store.usgs.gov

Any use of trade, firm, or product names is for descriptive purposes only and does not imply endorsement by the U.S. Government.

Although this information product, for the most part, is in the public domain, it also may contain copyrighted materials as noted in the text. Permission to reproduce copyrighted items must be secured from the copyright owner.

Suggested citation:

Hall, B.M., and Rus, D.L., 2013, Comparison of water consumption in two riparian vegetation communities along the central Platte River, Nebraska, 2008-09 and 2011: U.S. Geological Survey Scientific Investigations Report 2013-5203, 28 p., http://dx.doi.org/10.3133/sir20135203.

ISSN 2328-0328 (online) 


\section{Acknowledgments}

The authors thank Jim Jenniges, Environmental Specialist with Nebraska Public Power District, for all of his assistance at the grassland site, and the landowners, Gerald and Keith Trampe, for their cooperation with site access at the woodland site. The authors also thank Duane Woodward of the Central Platte Natural Resources District for his assistance in project planning and report preparation. The Central Platte Natural Resources District also is acknowledged for providing groundwater data for the grassland site. 


\section{Contents}

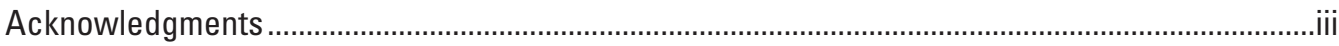

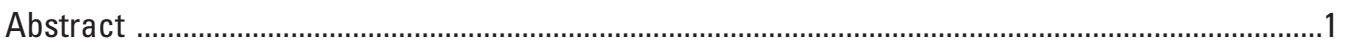

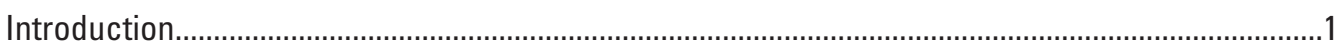

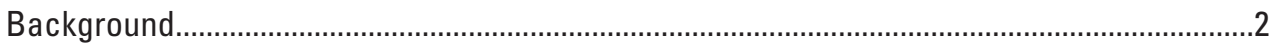

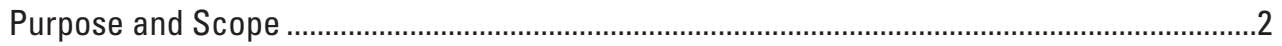

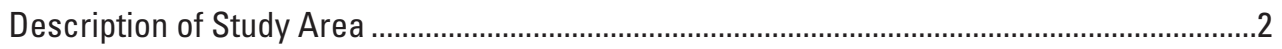

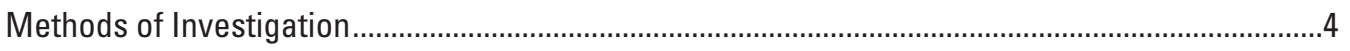

Site Selection and Characterization ................................................................................

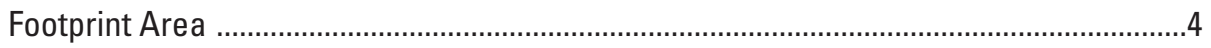

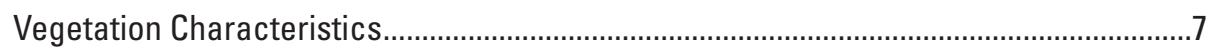

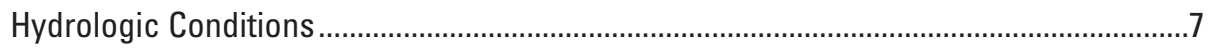

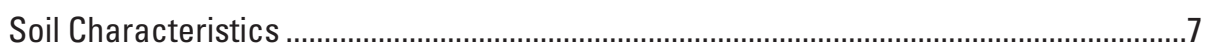

Micrometeorological Measurements …………………...............................................

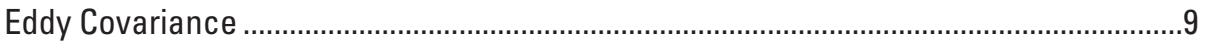

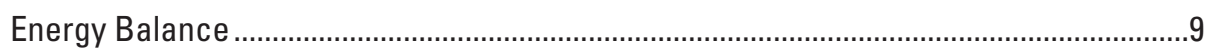

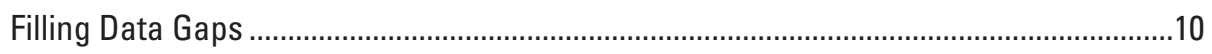

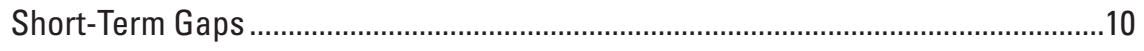

Long-Term Gaps ...........................................................................................

Validation of the Long-Term Gap-Filling Procedure ..............................................10

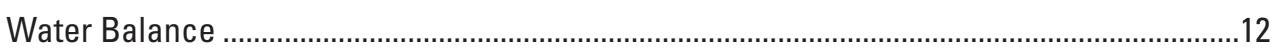



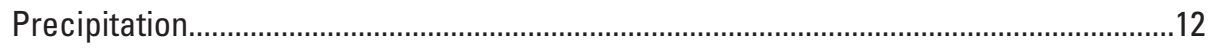

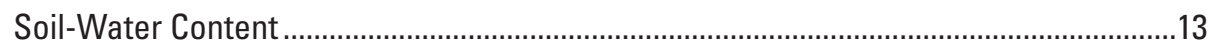

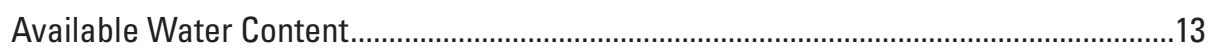

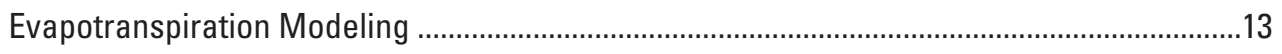

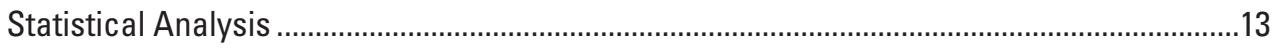

Estimating Evapotranspiration from Diel Groundwater Variations.........................................13

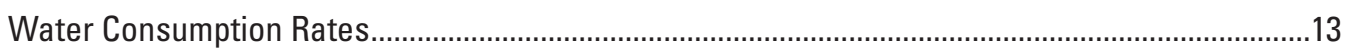



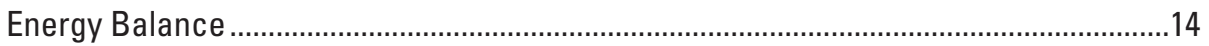

Direct Water Vapor Flux Comparison ........................................................................14

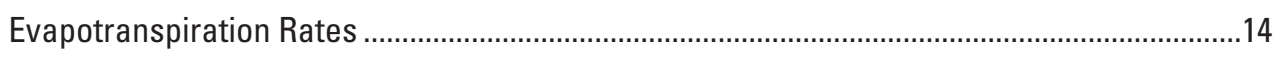

Differences in Seasonal Evapotranspiration Rates ......................................................14

Differences in Annual Evapotranspiration Rates .........................................................17

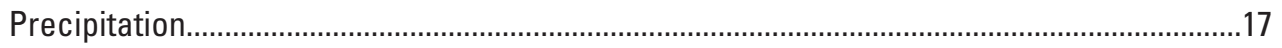

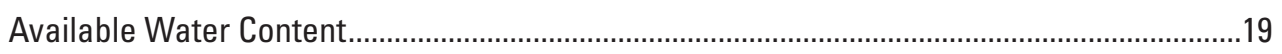

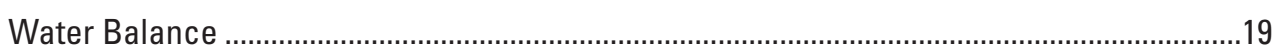

Differences in Water Balance between a Riparian Grassland and Woodland...............19



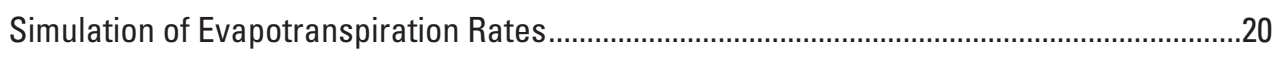

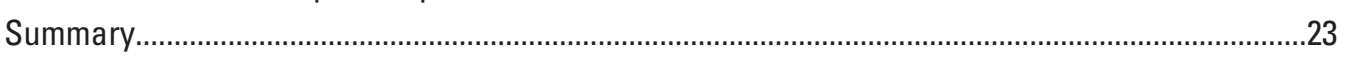

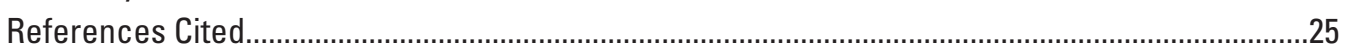


Appendix 1. Daily values of micrometeorological variables from riparian woodland study site near Odessa, Nebraska, January 1, 2008, to December 31, 2009, and January 1, 2011, to December 31, 2011...

Appendix 2. Daily values of micrometeorological variables from riparian grassland study site near Elm Creek, Nebraska, January 1, 2008, to December 31, 2009, and January 1, 2011, to December 31, 2011.

\section{Figures}

1. Map showing location of riparian woodland and grassland evapotranspiration study sites near Odessa and Elm Creek, Nebraska, respectively, and distribution of riparian woodland along the central Platte River.

2. Map showing data collection locations and probable flux source areas for micrometeorological instrumentation mounted on towers at $A$, a riparian grassland site; and $B$, a riparian woodland site

3. Graphs showing groundwater and nearby surface-water levels along the central Platte River at $A$, woodland and $B$, grassland study sites near Odessa and Elm Creek, Nebr., respectively, 2008-09 and 2011 ...

4. Graph showing relation of measured and estimated monthly evapotranspiration rates at riparian woodland study site near Odessa, Nebraska, 2008-09 and 2011

5. Graph showing relation of measured and estimated daily evapotranspiration rates at a riparian grassland study site near Elm Creek, Nebraska, 2011

6. Graphs showing daily, monthly, and annual evapotranspiration for woodland and grassland study sites near Odessa and Elm Creek, Nebraska, respectively, 2008-09 and 2011

7. Graphs showing daily, monthly measured and normal, and annual measured and normal precipitation for woodland and grassland study sites near Odessa and Elm Creek, Nebraska, respectively, 2008-09 and 2011.

8. Graph showing monthly average available water content in the top $1.5 \mathrm{~m}$ of the soil profile at woodland and grassland study sites near Odessa and Elm Creek, Nebraska, respectively, 2002-05, 2008-09, and 2011

9. Graphs showing relations among annual water balance terms for riparian woodland and grassland study sites near Odessa and Elm Creek, Nebraska, respectively, 2002-05, 2008-09, and 2011

10. Graph showing relation of measured and simulated monthly evapotranspiration rates at a riparian woodland study site near Odessa, Nebraska, 2008-09 and 2011 .....22 


\section{Tables}

1. Summary of monthly mean energy fluxes for riparian woodland and grassland study sites near Odessa and Elm Creek, Nebraska, respectively, 2008-09 and 2011

2. Annual water balance for a riparian woodland site near Odessa, Nebr., 2002-05, 2008-09, and 2011; and for a grassland site near Elm Creek, Nebr., 2008-09 and 2011 .

3. Average monthly crop coefficients for a riparian woodland study site near Odessa, Nebr., based on data from 2002-05, 2008-09, and 2011; and for a grassland study site near Elm Creek, Nebr., based on data from 2008-09 and 2011

\section{Conversion Factors}

\begin{tabular}{|c|c|c|}
\hline Multiply & By & To obtain \\
\hline \multicolumn{3}{|c|}{ Length } \\
\hline centimeter $(\mathrm{cm})$ & 0.3937 & inch (in.) \\
\hline millimeter (mm) & 0.03937 & inch (in.) \\
\hline meter $(\mathrm{m})$ & 3.281 & foot $(\mathrm{ft})$ \\
\hline kilometer $(\mathrm{km})$ & 0.6214 & mile (mi) \\
\hline \multicolumn{3}{|c|}{ Area } \\
\hline square meter $\left(\mathrm{m}^{2}\right)$ & 0.0002471 & acre \\
\hline square meter $\left(\mathrm{m}^{2}\right)$ & 10.76 & square foot $\left(\mathrm{ft}^{2}\right)$ \\
\hline \multicolumn{3}{|c|}{ Frequency } \\
\hline hertz $(\mathrm{Hz})$ & 1.0 & cycles per second \\
\hline \multicolumn{3}{|c|}{ Flow rate } \\
\hline millimeter per day $(\mathrm{mm} / \mathrm{d})$ & 0.03937 & inch per day (in/d) \\
\hline \multicolumn{3}{|c|}{ Mass } \\
\hline kilogram (kg) & 2.205 & pound avoirdupois (lb) \\
\hline \multicolumn{3}{|c|}{ Pressure } \\
\hline kilopascal $(\mathrm{kPa})$ & 0.1450 & pound per square inch $\left(\mathrm{lb} / \mathrm{in}^{2}\right)$ \\
\hline \multicolumn{3}{|c|}{ Density } \\
\hline kilogram per cubic meter $\left(\mathrm{kg} / \mathrm{m}^{3}\right)$ & 0.06242 & pound per cubic foot $\left(\mathrm{lb} / \mathrm{ft}^{3}\right)$ \\
\hline gram per cubic centimeter $\left(\mathrm{g} / \mathrm{cm}^{3}\right)$ & 62.4220 & pound per cubic foot $\left(\mathrm{lb} / \mathrm{ft}^{3}\right)$ \\
\hline \multicolumn{3}{|c|}{ Energy flux rate } \\
\hline watts per square meter $\left(\mathrm{W} / \mathrm{m}^{2}\right)$ & 0.0222 & $\begin{array}{l}\text { calorie per second per square } \\
\text { foot }\left(\mathrm{cal} / \mathrm{s} / \mathrm{ft}^{2}\right)\end{array}$ \\
\hline \multicolumn{3}{|c|}{ Power } \\
\hline watt (W) & 0.239 & calorie per second $(\mathrm{cal} / \mathrm{s})$ \\
\hline
\end{tabular}

Temperature in degrees Celsius $\left({ }^{\circ} \mathrm{C}\right)$ may be converted to degrees Fahrenheit $\left({ }^{\circ} \mathrm{F}\right)$ as follows:

${ }^{\circ} \mathrm{F}=\left(1.8 \mathrm{x}^{\circ} \mathrm{C}\right)+32$

Horizontal coordinate information is referenced to the North American Datum of 1983 (NAD 83).

Altitude, as used in this report, refers to distance above the vertical datum. 


\title{
Comparison of Water Consumption in Two Riparian Vegetation Communities along the Central Platte River, Nebraska, 2008-09 and 2011
}

\author{
By Brent M. Hall and David L. Rus
}

\section{Abstract}

The Platte River is a vital natural resource for the people, plants, and animals of Nebraska. A recent study quantified water use by riparian woodlands along central reaches of the Platte River, Nebraska, finding that water use was mainly regulated below maximum predicted levels. A comparative study was launched through a cooperative partnership between the U.S. Geological Survey, the Central Platte Natural Resources District, the Nebraska Department of Natural Resources, and the Nebraska Environmental Trust to compare water use of a riparian woodland with that of a grazed riparian grassland along the central Platte River. This report describes the results of the 3-year study by the U.S. Geological Survey to measure the evapotranspiration (ET) rates in the two riparian vegetation communities.

Evapotranspiration was measured during 2008-09 and 2011 using the eddy-covariance method at a riparian woodland near Odessa, hereinafter referred to as the "woodland site," and a riparian grassland pasture near Elm Creek, hereinafter referred to as the "grassland site." Overall, annual ET totals at the grassland site were 90 percent of the annual ET measured at the woodland site, with averages of 653 millimeters (mm) and $726 \mathrm{~mm}$, respectively. Evapotranspiration rates were similar at the grassland site and the woodland site during the spring and fall seasons, but at the woodland site ET rates were higher than those of the grassland site during the peak-growth summer months of June through August. These seasonal differences and the slightly lower ET rates at the grassland site were likely the result of differing plant communities, disturbance effects related to grazing and flooding, and climatic differences between the sites.

The annual water balance was calculated for each site and indicated that the predominant factors in the water balance at both sites were ET and precipitation. Annual precipitation for the study period ranged from near to above the normal precipitation of $640 \mathrm{~mm}$. Substantial precipitation fell in May and October 2008 that caused flooding along the Platte River in May of this especially wet year. There was a deficit in precipitation compared to ET at both sites in 2009 and 2011, leading to a net groundwater use of greater than $140 \mathrm{~mm}$ per year at the woodland site and greater than $55 \mathrm{~mm}$ per year at the grassland site. This indicates that the net annual groundwater use or recharge depends predominately upon the relation between ET and precipitation in these riparian areas with shallow soil layers above the groundwater table.

Prior research at the woodland site provided four additional annual water balances dating back to 2002 for comparison with the study period at the woodland site. Perhaps most striking in this comparison was the 25-percent increase in annual ET for 2008-09 and 2011 despite precipitation totals and potential ET rates that were within the range of those measured in 2002-05. As a result, the water balance indicates that groundwater was discharged 2 of the 3 years of the study. This likely was caused by higher groundwater levels and a healthier plant community in 2008-09 and 2011 relative to the drought-affected years of 2002-05. As a result of these changes, the crop coefficients developed for riparian woodlands during the prior research underestimated 2008-09 and 2011 annual ET rates by an average of 35 percent. Though new crop coefficients were developed by this study, the importance of soil-moisture stress and plant community successional dynamics need to be considered when applying these coefficients at other riparian sites or into the future. Nonetheless, their development and the data on which they are based may provide improved understanding of water consumption by riparian grasslands and riparian woodlands along the central Platte River.

\section{Introduction}

The Platte River is a vital natural resource for the people, plants, and animals of Nebraska. Surface water for irrigation is diverted directly from the Platte River, and groundwater irrigation supplies from the High Plains aquifer are at least partially replenished by the Platte River, greatly increasing agricultural production on land described by early explorers as the "Great American Desert" (Dick, 1975). Seven threatened or endangered species use the valley for habitat, including the 
whooping crane, piping plover, and interior least tern (U.S. Fish and Wildlife Service, 2013). It also is an internationally important habitat area for migratory water birds of the Central Flyway and is well-known for the one-half million sandhill cranes and the several million waterfowl that migrate annually through the valley (Norling and others, 1992).

Changes in water management and land use have led to noteworthy visual changes in the active river channel and adjacent wet meadows. A decrease in high-flow frequency resulting from upstream reservoir development has allowed channel sandbars to develop into forested islands and decreased the wetted channel area substantially from historical conditions (Johnson and Boettcher, 2000). The trees and other vegetation that now dominate these islands have become a concern to water managers because of the presumption that their water consumption is depleting the groundwater supplies needed for irrigation and, in turn, the surface-water supplies needed for irrigation and conservation of in-stream flows. Years of recent drought have intensified these concerns, and recent State legislation has led to the designation of most of the central reach of the Platte River as either over-appropriated or fully appropriated (Nebraska Department of Natural Resources, 2004).

However, the volume of water actually used by vegetation through evapotranspiration (ET) along the central Platte River is not well understood. Estimates vary, but it is possible that riparian woodlands consume water at or near maximum potential ET rates because of the availability of shallow groundwater.

\section{Background}

In 2002, the U.S. Geological Survey (USGS) and Nebraska Platte River Cooperative Hydrology Study Group (COHYST) began a cooperative study to better delimit ET estimates at two riparian woodland sites (dominated by cottonwood trees) located along the central Platte River near Odessa and Gothenburg, Nebraska. Results from that study indicate that (1) actual ET rates were 500-620 millimeters (mm; 20-24 inches) per year; (2) actual ET rates were substantially less than maximum rates estimated using data from nearby weather stations, indicating that even though shallow groundwater was available, plant water use was limited by internal regulation mechanisms and external environmental factors; and (3) ET rates were most strongly affected by humidity and the availability of soil water and groundwater (Landon and others, 2009).

An important gap in understanding of riparian ET along the central Platte River is how ET by riparian woodlands compares to that of riparian grasslands. This question is especially relevant in the context of ET salvage, a concept in which less beneficial plant communities (such as unmanaged riparian woodlands) are replaced with alternative plant communities that may provide more directly beneficial uses (such as might be attributed to riparian grasslands), while simultaneously increasing water availability for other purposes. Results from
Landon and others (2009) for two riparian woodlands suggest that water savings from the removal of riparian woodlands may not be as substantial as previously estimated. Landon and others (2009), however, lacked a comparative measure of riparian grassland ET that is needed to evaluate the net replacement effect on water availability. Another shortcoming of their study is that it was primarily done during a period of drought, which may not be representative of the long-term average conditions.

To fill this gap in information, a comparative study was launched through a cooperative partnership between the USGS, the Central Platte Natural Resources District, the Nebraska Department of Natural Resources, and the Nebraska Environmental Trust to directly compare ET measured using consistent methods at an existing riparian woodland site near Odessa, Nebr., and a grazed grassland site located along the central Platte River near Elm Creek, Nebr. (fig. 1).

\section{Purpose and Scope}

The purpose of this report is to document the study and compare results of water consumption measured by micrometeorological monitoring of evapotranspiration from two different riparian vegetation communities, woodland and grassland, along the central Platte River in Nebraska during 2008-09 and 2011. Eddy-covariance measurement techniques are described, and ET values are compared with energy and water balances and are summarized daily, monthly, and annually. The use of crop coefficients to simulate ET from riparian woodlands is evaluated, and new crop coefficients are developed for both study locations.

\section{Description of Study Area}

The central Platte River valley is a broad flood plain containing the braided channel of the Platte River. For the purpose of this report the central Platte River is considered to be the reach of the Platte River that stretches from the confluence of the North and South Platte Rivers in Lincoln County, Nebr., (not shown) to the confluence of the Platte and Loup Rivers in Platte County, Nebr. (not shown). In this area, groundwater and surface water are hydrologically connected. Groundwater levels on the riparian islands between river channels are shallow and respond to flows within the river, even indicating fluctuations that correspond to the power-generation cycling of the Platte River flows.

The Platte River flow throughout much of Nebraska is highly managed through a series of dams and diversions that supply irrigation and power canals. The system that directly affects flows near the study sites, operated by the Central Nebraska Public Power and Irrigation District, has been operational since 1941 and includes a major dam, diversion, and an irrigation and power-supply canal (Central Nebraska Public Power and Irrigation District, 2013) with a return point 


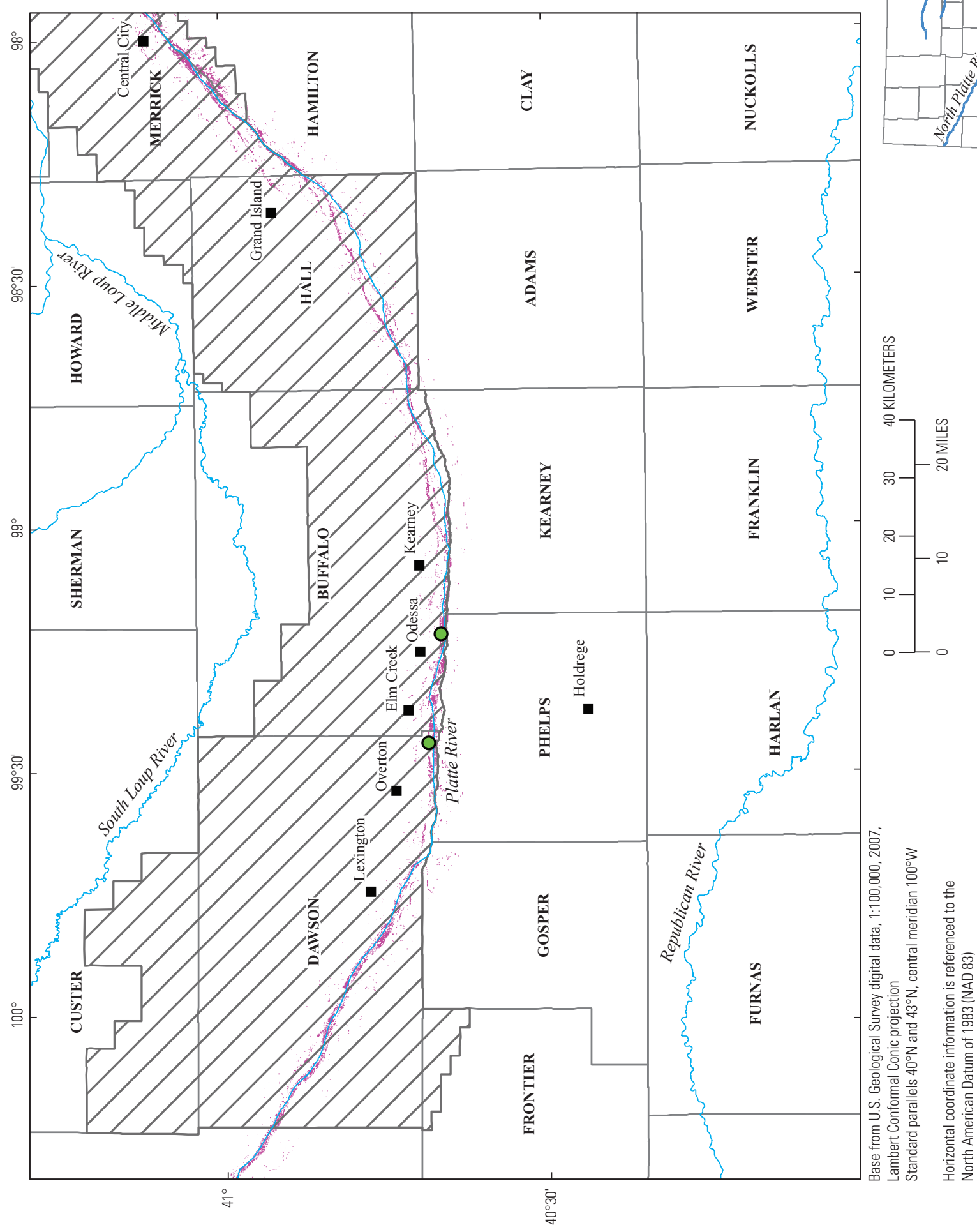

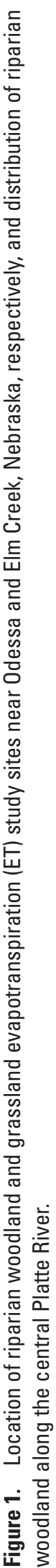


just 20 kilometers $(\mathrm{km})$ upstream from the grassland site. As a result of power generation, during the non-irrigation seasons of the 2008 and 2009 study years a daily flow cycle with stage fluctuations of as much as $0.6 \mathrm{~m}$ often was observed in the central Platte River at the grassland site, with slightly lesser fluctuations further downstream at the woodland site.

The grassland site was dominated by grasses, with no trees present except along some of the distant banks of the river channels. The predominant grass species, with approximately 80 percent coverage, was Kentucky bluegrass (Poa pratensis). The grass height varied based on the season and the grazing pressure, ranging from less than 0.05 meter $(\mathrm{m})$ (recently and heavily grazed) to greater than $0.6 \mathrm{~m}$. Throughout the grassland small clumps of taller grass species were present, covering 15 to 20 percent of the site. These clumps varied in height but were typically in the range of $0.6 \mathrm{~m}$ to $1.2 \mathrm{~m}$ and were composed mainly of big bluestem (Andropogon gerardii), prairie cordgrass (Spartina pectinata), or switchgrass (Panicum virgatum). The composition of the remainder of the grassland changed seasonally, but included small amounts of thistles, annual ragweed (Ambrosia artemisiifolia), Russian olive (Elaeagnus angustifolia) shrubs, and other grass and forb species.

Grazing at the grassland site affected the vegetation at the plant scale as well as the community composition, making the interpretation of ET rates more difficult there. However, it seemed likely that grasslands along the river would eventually be grazed, and this form of land management was intentionally included in the study. The grassland site was grazed during the entire growing season of 2008 and from May through June 2009. During these periods, the average vegetation height varied between 0.14 and $0.23 \mathrm{~m}$. There was no grazing during the latter part of the 2009 growing season nor the entire year of 2011. Average vegetation height during these periods varied between 0.33 and $0.59 \mathrm{~m}$.

The vegetation at the woodland site consists of cottonwood canopy with a shrub and grass understory and is described in detail by Landon and others (2009).

\section{Methods of Investigation}

Measurement of water consumption through ET of two riparian plant communities (woodland and grassland) within the central Platte River valley was monitored using the eddycovariance method. Additionally, meteorological, biological, and hydrologic data were collected as possible explanatory variables. The study partially continued the investigation of water consumption rates by riparian woodland at a study location near Odessa, Nebr., hereinafter referred to as "the woodland site," studied during 2002-05 (Landon and others, 2009), while also adding the investigation of water consumption of riparian grassland, hereinafter referred to as "the grassland site." The woodland-site measurements were collected at the same location (and using the same tower and equipment) as described by Landon and others (2009).

\section{Site Selection and Characterization}

As with the selection of the riparian woodland site in 2001 (Landon and others, 2009), the riparian grassland site was selected based upon several factors. These included, but were not limited to, having characteristics representative of a large area of riparian grassland along the Platte River, access to the property, and the availability of existing site information and infrastructure (for example, existing observation wells). Based on aerial imaging and local recommendations, two sites were considered. The site selected for use was a riparian grassland pasture located on an island between channels of the Platte River (fig. $2 A$ ) near Elm Creek, Nebr.

\section{Footprint Area}

To ensure that the measured turbulent energy fluxes (latent-heat and sensible-heat flow per unit area) were truly representative of the study area, it was necessary to estimate the footprint, or the land area contributing to the turbulent fluxes, at the proposed grassland monitoring location. A preliminary estimate of the footprint was calculated using the equations detailed by Schuepp and others (1990) assuming an instrumentation height of $2.9 \mathrm{~m}$ over a canopy of vegetation with an average height of $0.2 \mathrm{~m}$. Following Landon and others (2009), the roughness length and zero plane displacement were reported as 0.08 and 0.75 of the canopy height, respectively.

Based on these assumptions, 85 percent of the fluxes measured under neutral conditions (where the effects of wind dominate the buoyancy effects of the air) would originate within $530 \mathrm{~m}$ of the sensors (fig. $2 A$ ). However, because unstable conditions (where buoyancy effects dominate wind effects) and taller vegetation both serve to reduce the size of the footprint and both also are typically experienced during times of higher ET, it was assumed that the actual flux contribution from a footprint with a radius of $530 \mathrm{~m}$ will exceed 85 percent.

At the grassland site, open grassland was the predominant land cover (50.7 percent) within the pre-study footprint radius of $530 \mathrm{~m}$. Riparian woodlands accounted for 26.7 percent of the footprint area but were primarily at the edges of the footprint along the river channels. Wetlands accounted for 19.9 percent of the footprint area, with the wetland area divided evenly between backwater channel marshes and subirrigated meadows within the grassland. The remainder of the footprint area ( 2.7 percent) was the low-flow river channel of the Platte River. Although much of the flux measured at the tower will be from the targeted grassland vegetation, an unknown portion of the flux will originate from beyond the grassland over the wetted river channel or in the woodlands.

The woodland site was reported by Landon and others (2009) to have an 85-percent source area upwind footprint radius of $800 \mathrm{~m}$ (fig. $2 B$ ). The land cover within this radius was reported to be mostly woody vegetation (55.8 percent) and open spaces in the forest primarily occupied by grasses (21.0 percent), with minor flux contributions originating outside of the woodland (Landon and others, 2009). 
$\boldsymbol{A}$

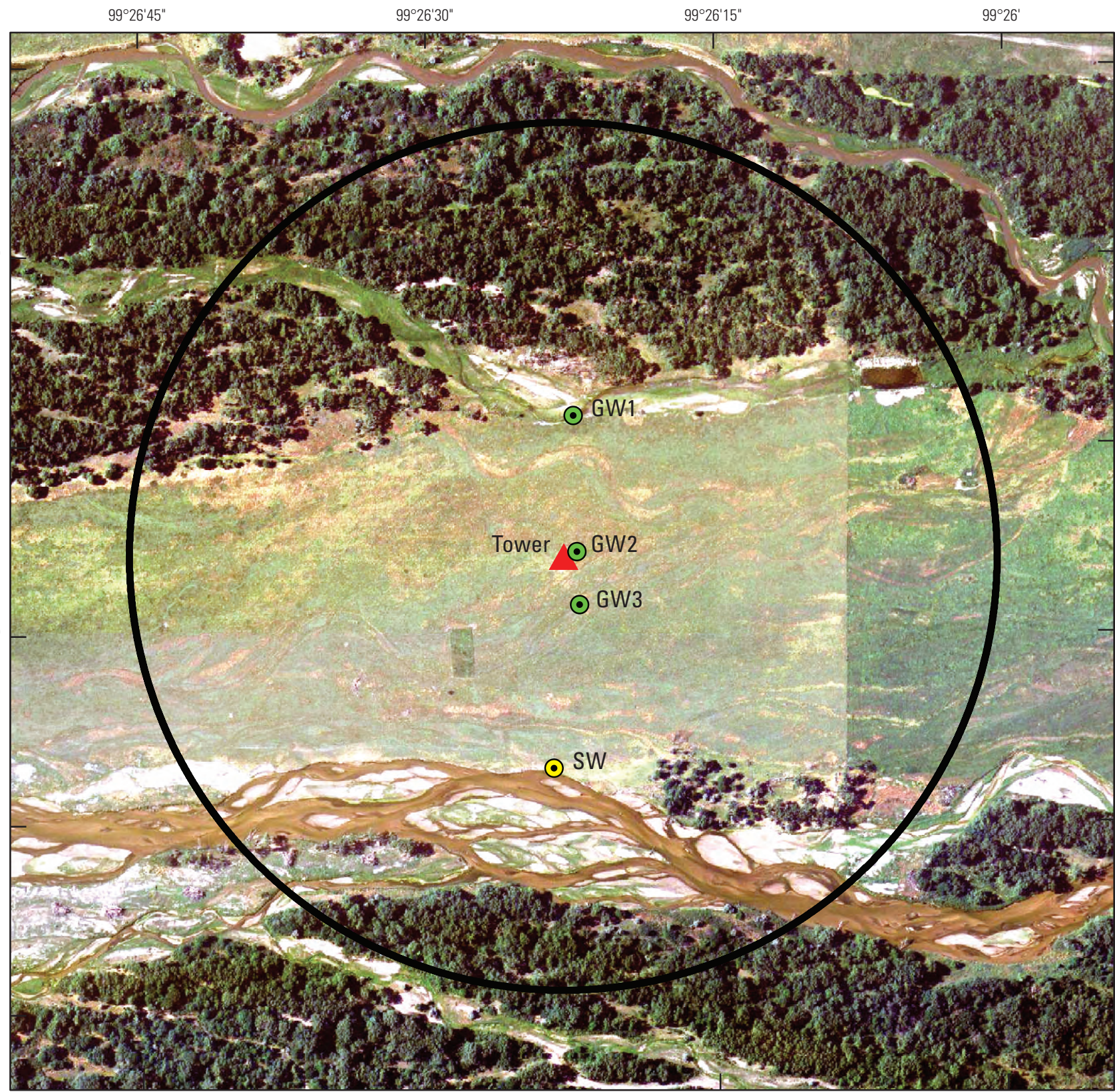

Base from U.S. Department of Agriculture, Farm Service Agency, Aerial Photography Field Offie, digital data, 1:12,000, 2003,

Lambert Conformal Conic projection

Standard parallels $40^{\circ} \mathrm{N}$ and $43^{\circ} \mathrm{N}$, central meridian $100^{\circ} \mathrm{W}$

Horizontal coordinate information is referenced to the North American Datum of 1983 (NAD 83)


Figure 2. Data collection locations and probable flux source areas for micrometeorological instrumentation mounted on towers at $A$, a riparian grassland site; and $B$, a riparian woodland site. 
B

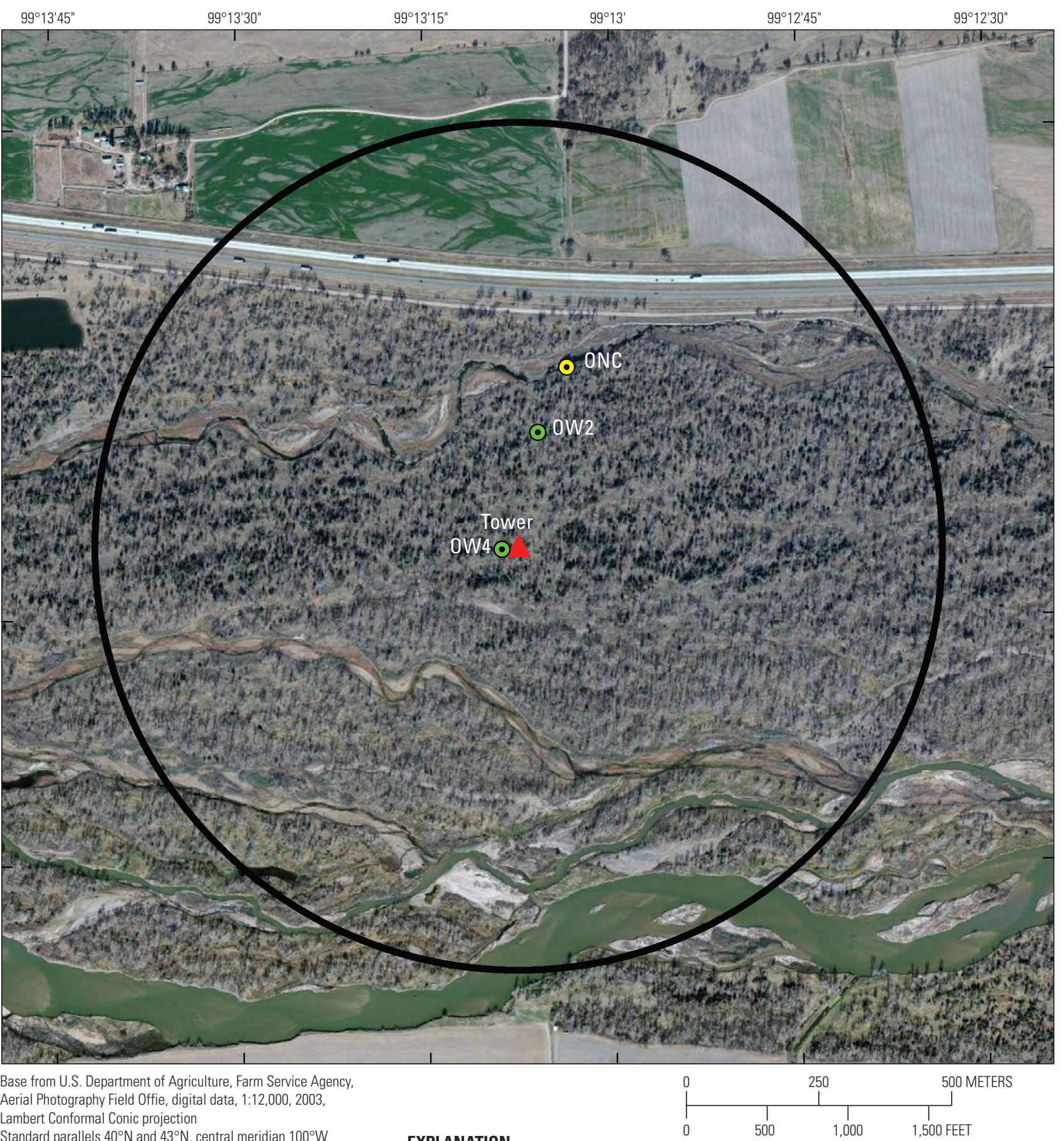

Standard parallels $40^{\circ} \mathrm{N}$ and $43^{\circ} \mathrm{N}$, central meridian $100^{\circ} \mathrm{W}$

Horizontal coordinate information is referenced to the North American Datum of 1983 (NAD 83)
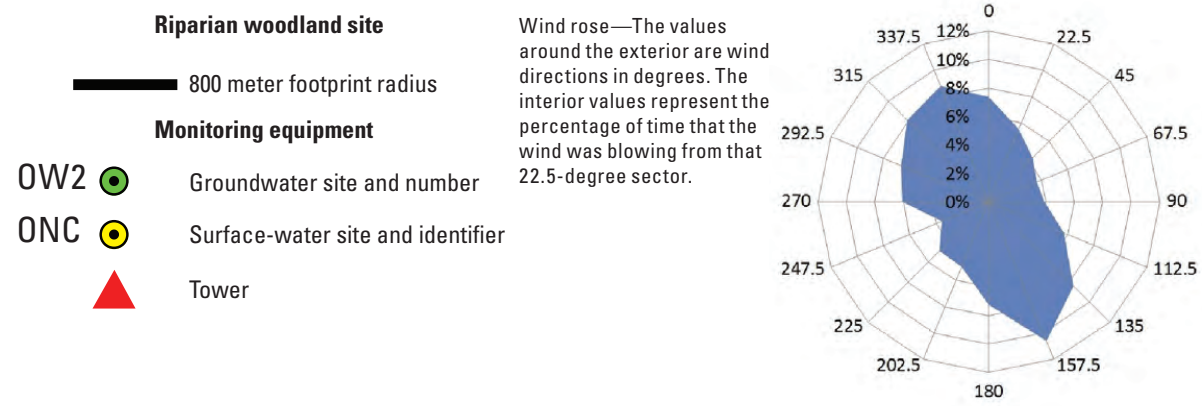

Figure 2. Data collection locations and probable flux source areas for micrometeorological instrumentation mounted on towers at $A$, a riparian grassland site; and $B$, a riparian woodland site.-Continued 


\section{Vegetation Characteristics}

The dimensionless leaf area index (LAI) was measured approximately monthly at the woodland site from 2008 to 2011 using hemispherical photography as detailed by Landon and others (2009). The LAI data indicated a timing and pattern consistent with that reported by Landon and others (2009), but the LAI values measured in this study did reach higher levels, with a peak value of 1.55 compared to 1.40 in Landon and others (2009). Peak LAI values decreased each year from 2002 to 2004, suggesting that the vegetation community likely was responding to drought-related water stress by reducing vegetative biomass. In contrast, peak LAI values increased each year from 2008 to 2011, likely as a result of increased moisture observed during this study period, and possibly a result of a few more years of tree growth and a regrowth of understory vegetation following the drought. At the grassland site, LAI data were obtained from remotely sensed data collected by the Moderate Resolution Imaging Spectroradiometer (MODIS) satellite (Knyazikhin and others, 1999; MODIS data available at https://lpdaac.usgs.gov/). However, the MODIS LAI values did not tend to be sensitive to the grazing effects observed on the ground. This was probably because of the coarse spatial resolution [1 km] of the MODIS data (that included pixels partly covered by riparian woodland adjacent to the grassland). Subsequently, these LAI values were not used for further analysis.

\section{Hydrologic Conditions}

The woodland site and the grassland site experienced localized flooding in 2008 and 2011. In late May 2008, a period of high regional precipitation presumably led to shortterm flooding along the central Platte River, and overbank flow was observed through the study area at both sites. The characteristics of the 2011 flood were much different than the flood of 2008 (U.S. Geological Survey, 2013). Heavy mountain snowpack in the headwaters region of the Platte River presumably resulted in sustained high releases from the upstream reservoirs along the Platte River. Regardless of the cause, high flows along the Platte River led to a high water table throughout the summer of 2011.

Depth to groundwater measured in well GW2 averaged $1.2 \mathrm{~m}$ and varied between 0.2 and $1.5 \mathrm{~m}$ during 2008-09 and 2011 at the grassland site (fig. 3). In contrast, depth to groundwater (averaging measurements in wells OW2 and OW4) averaged $0.8 \mathrm{~m}$ and varied between -0.5 (above land surface) and $1.3 \mathrm{~m}$ at the woodland site. At both sites, groundwater levels typically were lower than adjacent river levels, suggesting that the Platte River was a losing reach with respect to groundwater/surface-water interaction during the course of this study.

\section{Soil Characteristics}

There was a difference between the two sites in the stratigraphy of the first $1 \mathrm{~m}$ of the soil profile. The woodland site had a 10- to 20-centimeter $(\mathrm{cm})$ thick surface layer of sandy loam overlaying a 40 - to $50-\mathrm{cm}$ thick layer of sand containing lenses of silt and a base of coarse sand and fine gravel (Landon and others, 2009). Grassland-site soils were documented during soil-water content sensor installation by digging trenches and were found to be generally finer than the woodland-site soils. Two soil profiles were described and both had a 40- to $45-\mathrm{cm}$ thick layer of silt loam overlaying a clay loam to loam layer 70 - to $80-\mathrm{cm}$ thick, with a sandy to sandy loam layer beneath.

The bulk density values at the grassland site generally increased with depth but were lower than those reported at the woodland site (Landon and others, 2009), reflecting the finer particle sizes (and possibly higher organic content) of the soil at the grassland site. The dry bulk density increased from an average value of 0.84 grams per cubic centimeter $\left(\mathrm{g} / \mathrm{cm}^{3}\right)$ at a depth of $5 \mathrm{~cm}$ to an average of $1.27 \mathrm{~g} / \mathrm{cm}^{3}$ at depths of $100 \mathrm{~cm}$ or greater (see the Soil-Water Content section).

\section{Micrometeorological Measurements}

Micrometeorological equipment was installed at the grassland site at a height of $2.8 \mathrm{~m}$ on a $3.0-\mathrm{m}$-tall tower. Major system components included a sonic anemometer and krypton hygrometer to measure turbulent energy fluxes, a 2-component net radiometer and soil heat flux plates to measure radiant energy fluxes, and wind, temperature, and precipitation sensors. For full details on the equipment used, see Landon and others (2009). An identical set of equipment was re-installed at a height of $26.1 \mathrm{~m}$ on a 27.4-m-tall tower at the riparian woodland site. Data collection began at both sites on October 1, 2007, and continued through December 31, 2011. All data were averaged for 30-minute intervals (except precipitation, which was totaled every 30 minutes) and collected remotely on a daily basis using cellular modems for weekly inspections. Periodic visits to the field sites also were made to clean and inspect equipment.

The methods outlined in detail by Landon and others (2009) were generally followed throughout the data-collection and analysis process. These included measuring raw ET with an eddy-covariance system and processing and correcting the data to produce a complete annual record. Processing and correcting the data included removing erroneous data, rotating wind vector coordinates, and applying corrections to account for air-density fluctuations, and sensor sensitivity to oxygen; and for measuring the air temperature sonically. A few exceptions (detailed in the Eddy Covariance and Energy Balance sections) include a different method of coordinate rotation for 

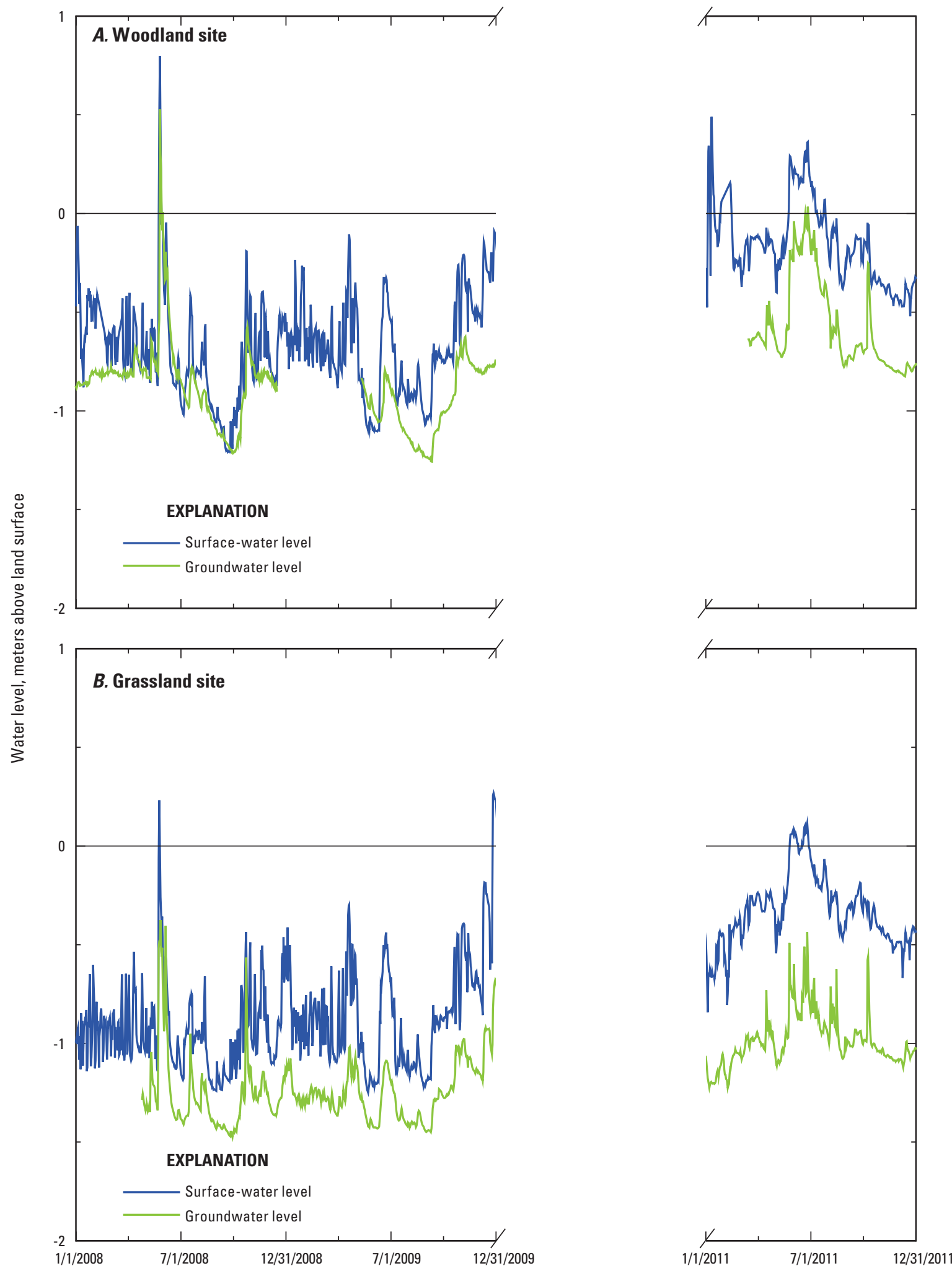

Figure 3. Groundwater and nearby surface-water levels along the central Platte River at $A$, woodland and $B$, grassland study sites near Odessa and Elm Creek, Nebr., respectively, 2008-09 and 2011. Grassland surface-water data from U.S. Geological Survey station 06768035 (U.S. Geological Survey, 2013); grassland groundwater data from well GW2 (appendix 2); woodland groundwater data calculated from wells OW2 and OW4 (appendix 1). 
the sonic anemometer data, not accounting for energy storage in vegetation, and not monitoring either sap flux in individual trees or through fall precipitation.

\section{Eddy Covariance}

Evapotranspiration was measured using the eddycovariance method, and the data were processed as described by Landon and others (2009) with one exception during data processing. Instead of rotating wind vector coordinates by fitting a sinusoidal curve to the data, the data from each 30-minute averaging period were rotated twice to align the axis of the sonic anemometer with the mean wind direction. As detailed by Lee and others (2004), this coordinate rotation is accomplished by first rotating the coordinates on a horizontal plane into the mean wind direction, thereby eliminating the mean crosswind component, and then rotating or tipping the horizontal plane of the new coordinates to eliminate the mean vertical wind component, leaving a coordinate system aligned with mean stream-wise wind.

This different method of coordinate rotation was selected for several reasons. After removing the sonic anemometer for factory calibration and remounting it, the sinusoidal equations used by Landon and others (2009) would no longer be applicable because of slight differences in sensor position or orientation. Additionally, the generally uniform nature of the vegetation and terrain at the grassland site does not require the complexity of modeling, and a preliminary analysis of the data from the woodland site comparing results from a newly generated sinusoidal curve to those from rotation methods indicated less than 1 percent difference in the total ET.

Late in the study (May 2011), the eddy-covariance systems were modified. A new sensor to measure water vapor flux using infrared analysis (LI-COR, Inc., model LI-7500A) was added at each site. This sensor allowed for direct comparison of water vapor flux measurements with the ultravioletbased krypton-hygrometer water vapor flux sensor originally deployed with the system. At the same time, data-storage capacity was expanded to allow for the storage of raw data collected at a frequency of $10 \mathrm{hertz}(\mathrm{Hz})$ from the sonic anemometer and both gas analyzers. Processing of the $10-\mathrm{Hz}$ data was completed using the EddyPro software program (LI-COR, Inc., Lincoln, Nebr., version 3.0.0) to produce flux values averaged for a 30 -minute time period.

\section{Energy Balance}

The form of the surface-energy balance equation used for this project was as follows:

$$
R_{n}-G=\lambda E+H
$$

where

$$
\begin{array}{cl}
R_{n} & \text { is the net radiation, } \\
G & \text { is the soil heat flux, }
\end{array}
$$

$\begin{array}{cl}\lambda E & \text { is the latent-heat flux, and } \\ H & \text { is the sensible-heat flux. }\end{array}$

All terms have units of energy flow per unit area, or watts per square meter $\left(\mathrm{W} / \mathrm{m}^{2}\right)$. This omits the term accounting for the energy storage in plant biomass used by Landon and others (2009) because of its presumed negligible role in the energy balance. Landon and others (2009) reported that the average monthly plant biomass energy storage was $0.0 \mathrm{~W} / \mathrm{m}^{2}$ at the woodland site, with absolute magnitudes for the entire study period no greater than $0.07 \mathrm{~W} / \mathrm{m}^{2}$ on a monthly basis. Since surface water was present only during infrequent, unpredictable, and short periods of overland flooding, energy storage within surface water was considered to be negligible on longer time scales and was not included in the energy balance.

The energy balance equation was rearranged into a ratio of the turbulent heat fluxes with the energy available for surface heating to evaluate the measurement errors of the energy components (Gu and others, 1999; Landon and others, 2009). This new, dimensionless term, called the energy balance ratio (EBR), is defined as follows:

$$
E B R=(\lambda E+H) /\left(R_{n}-G\right)
$$

The 30-minute EBR and the EBR calculated from daily sums of the energy fluxes were used to determine data quality. Annual sums of energy fluxes were used to obtain a long-term average (annual) EBR.

To better account for a presumed negative bias in the measurement of long-wave radiation at the study sites, net radiation data collected by a 2-component net radiometer were corrected following the procedures detailed by Landon and others (2009). A 4-component net radiometer was deployed at the grassland site, and regression equations accounting for the underestimation of long-wave radiation were developed for daytime and night conditions. The relations developed by Landon and others (2009) were used to correct the data collected with the 2-component net radiometer at the woodland site. As was observed by Landon and others (2009), this correction improved the energy balance but still did not bring complete energy balance closure.

Before the study, the micrometeorological equipment was checked and recalibrated by manufacturers. However, the annual EBR at the grassland site for the first 2 years of the study averaged 0.564 , much lower than the value of 0.932 from the woodland-site data and low enough to raise concerns about the quality of the turbulent flux data. These suspicions resulted in switching the sonic anemometers between the two sites, but this did not change the data quality at either site, so the problem at the grassland site was assumed to be with the krypton hygrometer. The deployment of the infrared gas analyzer in May 2011 improved the EBR at the grassland site, confirming that the krypton hygrometer had malfunctioned. The EBR for the new sensor for the 7 months of deployment was $0.74-$ not as good as the woodland site, but much closer to the average EBR of 0.84 reported by Wilson and others (2002) from the 
review of 50 site-years of data at 22 Fluxnet sites. As a result of this equipment malfunction all latent-heat flux values from the krypton hygrometer at the grassland site were considered unreliable and were therefore discarded.

\section{Filling Data Gaps}

As a result of factors such as weather, sensor limitations, sensor failure, or power limitations, approximately 16 percent of the eddy-covariance data at the woodland site were either missing or of poor quality based upon sensor diagnostics and were discarded. To produce a complete data record, these gaps, most of which were short (a few hours or less), needed to be filled. Gaps were filled following the procedures outlined below and detailed by Landon and others (2009).

\section{Short-Term Gaps}

Periodically, short-term gaps (generally of 2 hours or less) not associated with wet atmospheric conditions were present in the raw data. These gaps were filled using linear interpolation between the measured values that were adjacent in time.

Many gaps were associated with condensation on the sensor heads of the krypton hygrometer and, to a lesser degree, the sonic anemometer, and typically happened during a precipitation event or morning dew/frost. Potential evapotranspiration (PET) is the theoretical rate at which a short, uniform, green crop would transpire if water was not limited, and was therefore used to fill these gaps. This was done by first calculating PET for each 30-minute-averaging period using the Priestley-Taylor equation (Priestley and Taylor, 1972) similar to that done by Landon and others (2009). PET was then scaled to the 14-day moving average of the 30 -minute EBR to arrive at the estimate of latent-heat flux $(\lambda E)$. Sensible-heat flux $(H)$ was then estimated as the residual of the energy balance.

\section{Long-Term Gaps}

Long-term gaps in the data record (such as during the sensor failure at the grassland site where latent-heat fluxes were discarded) were estimated as the residual of the energy balance equation by rearranging equation 2 as follows:

$$
\lambda E=E B R\left(R_{n}-G\right)-H
$$

Throughout this report these data, especially those replacing the missing record at the grassland site, are referred to as "estimated ET."

Occasionally, during these time periods $H$ was missing. This was handled in one of two ways, depending upon the length and cause of the gap. When the gap in $H$ was short, it was filled with linear interpolation. Longer gaps generally were associated with precipitation events and were filled using the PET scaling method described for filling short-term gaps. With the missing latent energy record at the grassland site, it was unreasonable to use the long-term measured energy balance ratio to scale the net radiation, so an energy balance ratio (EBR) of 0.74 obtained from the 7-month deployment of the infrared gas analyzer was used instead to scale the PET.

\section{Validation of the Long-Term Gap-Filling Procedure}

To validate the use of equation 3 for long-term gap filling, the energy-balance approach was applied to the 30-minute data from the woodland site (using the EBR of 0.923 measured there), providing a comparison of estimated values to measured and verified values. Although some variability was present between the measured and estimated ET rates for daily values, the monthly (fig. 4) and annual estimated ET measurements balanced this variability. For each of the 3 years of the study, the annual sum of the estimated ET values was within 3 percent of the measured ET total. Based upon this validation, estimated 30-minute ET values for the entire study period were generated for the grassland site.

The long-term gap filling procedure was validated further with data collected in summer 2011. The installation of the second water vapor flux sensor during this period allowed for a comparison between the estimated ET values at the grassland site and direct ET measurements expected to be of higher accuracy. The sensor was installed and operational for the last 214 days of the study, a time period that included most of the growing season and the fall and early winter dormancy. The total estimated ET for the period of comparison was $451 \mathrm{~mm}$, compared to a total measured ET of $452 \mathrm{~mm}$, with some daily variations (fig. 5) but generally a good agreement. The daily differences balanced when considered on longer time scales. Overall, these data were confirmation of the validity of the selected ET estimation technique at the grassland site, and estimated 30-minute ET values were generated for the entire study period of 2008-09 and 2011.

The lack of energy balance closure observed at the grassland site does raise some concerns with the estimated ET. The assumption made in data processing (following Landon and others, 2009) was that the available energy (as measured by the net radiometer) was overestimated and was therefore scaled down to achieve closure. The contrast to this assumption would be that the turbulent energy fluxes were underestimated and should be higher. To delimit the measurement error, ET also was calculated for both sites on a daily basis by forcing an energy-balance closure. This value was used as the upper limit of possible ET, the measured and gapfilled values represent the lower limit of possible ET, and the mean of the two limiting values was used and reported as the best estimate for the ET during the study. It is important to note that the range between the measured ET and the ET from closing the energy balance is much larger at the grassland site because of the lower measured EBR. 


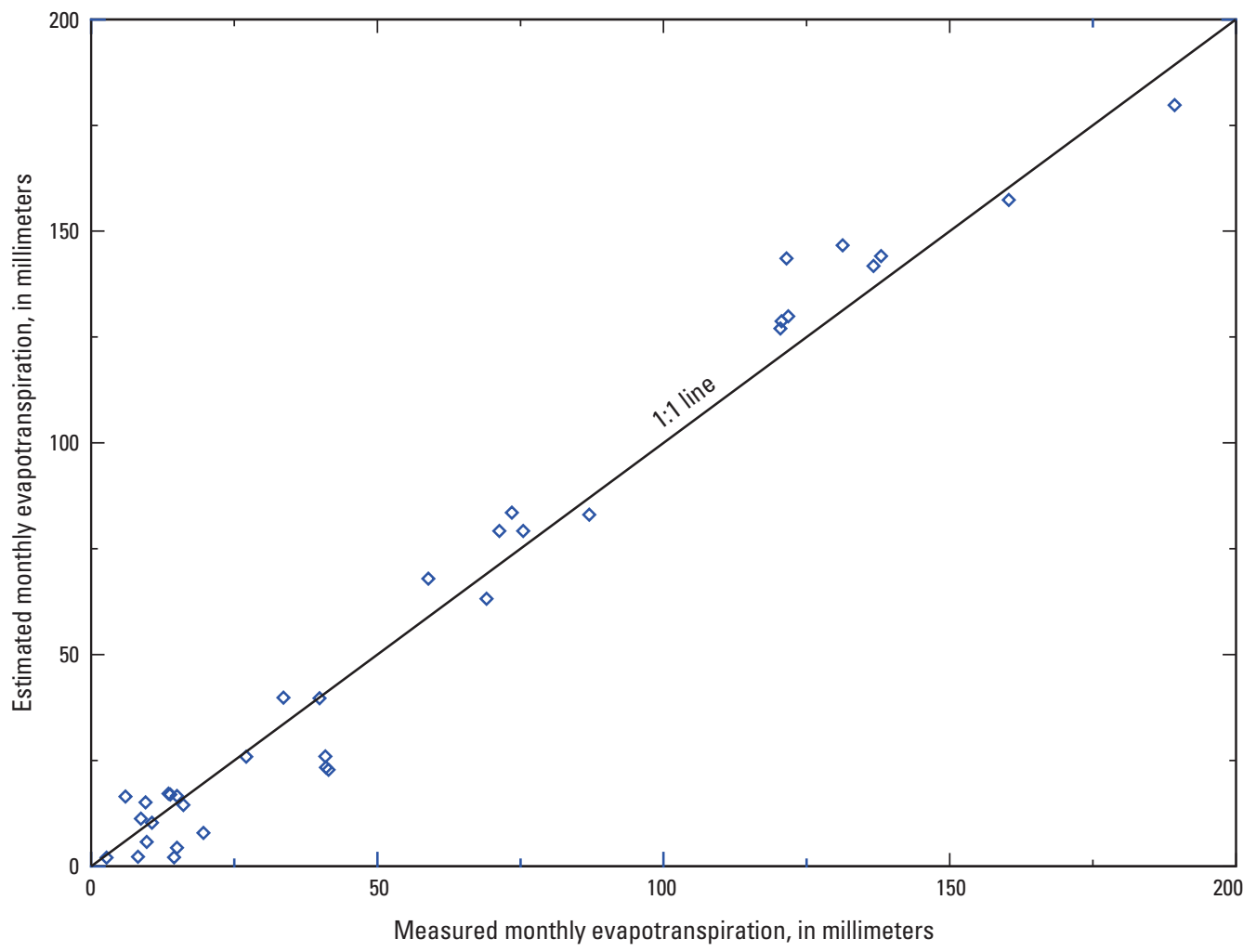

Figure 4. Relation of measured and estimated monthly evapotranspiration rates at riparian woodland study site near Odessa, Nebraska, 2008-09 and 2011.

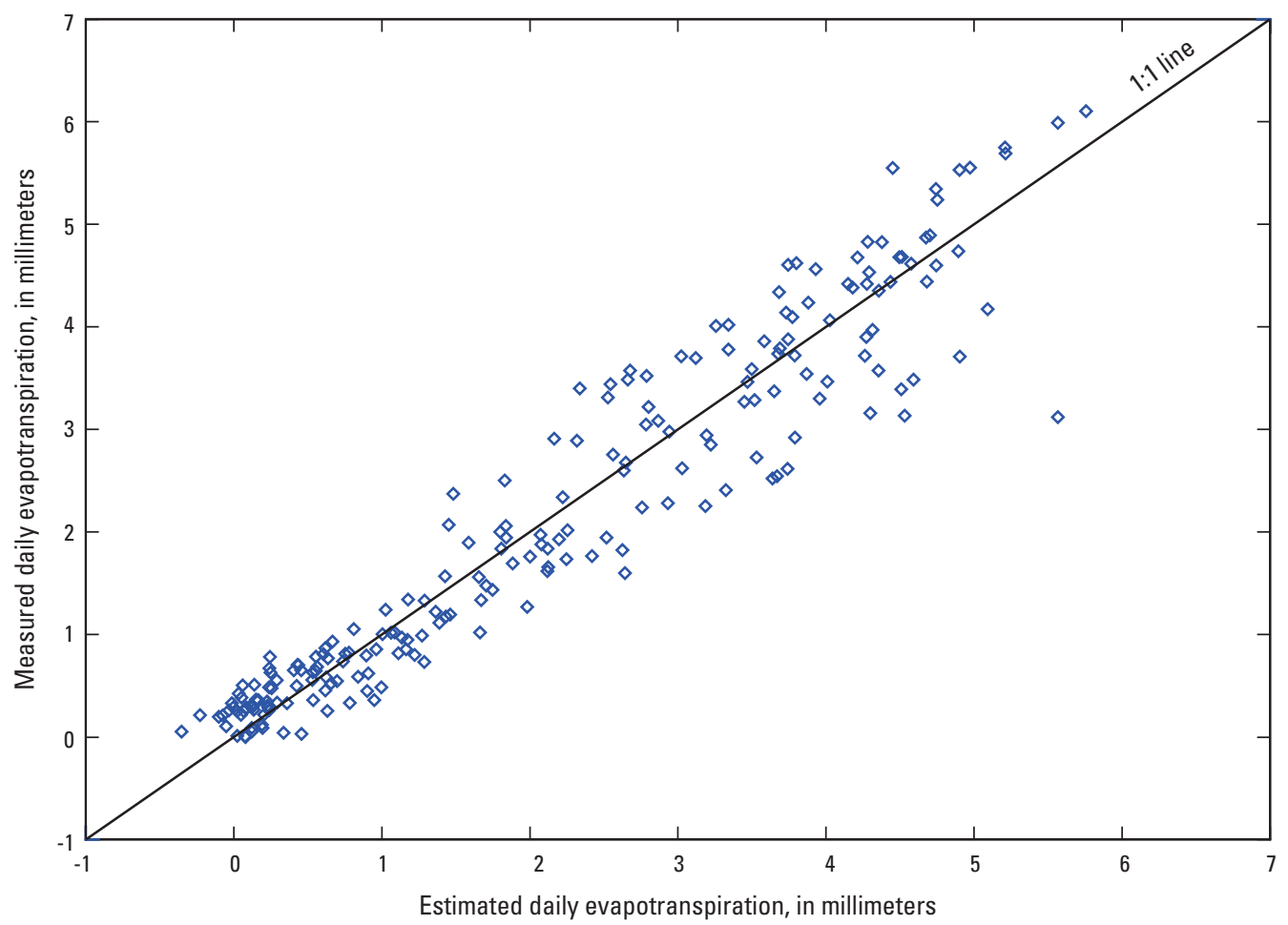

Figure 5. Relation of measured and estimated daily evapotranspiration rates at a riparian grassland study site near Elm Creek, Nebraska, 2011. 


\section{Water Balance}

In an attempt to quantify the interactions of the riparian system with groundwater, a water balance was calculated for a control volume of the area included within the footprint of the eddy-covariance equipment at both sites. Following the technique of Landon and others (2009), the form of the waterbalance equation used was as follows:

$$
G W_{\text {in }}-G W_{\text {out }}=E T-P+\Delta V Z W+\Delta G W
$$

where

$$
\begin{aligned}
& G W_{\text {in }} \text { is the groundwater inflow, } \\
& G W_{\text {out }} \text { is the groundwater outflow, } \\
& E T \text { is the evapotranspiration, } \\
& P \text { is the precipitation, } \\
& \triangle V Z W \text { is the change in vadose-zone-water storage } \\
& \text { within the control volume, and } \\
& \Delta G W \text { is the change in groundwater storage within } \\
& \text { the control volume. }
\end{aligned}
$$

All terms are expressed as a depth of water per unit area with units of millimeters per year ( $\mathrm{mm} / \mathrm{yr})$, and calculations were made annually based on the calendar year. A positive value for the term $G W_{\text {in }}-G W_{\text {out }}$ indicates that the system is using regional groundwater and acting as a net groundwater sink, whereas a negative value indicates that there was groundwater recharge from the control volume to the regional system during the evaluation period. Positive values of $\triangle V Z W$ and $\triangle G W$ correspond to increases in storage within the control volume.

By measuring precipitation, ET with the eddy-covariance equipment, vadose-zone moisture with vertical arrays of water-content reflectometers (Campbell Scientific, Inc., model CS615), and groundwater levels with shallow piezometers (wells), the groundwater use or recharge was calculated. Annual change in vadose zone storage was calculated by integrating the measured soil moisture within the monitored soil layers, and annual groundwater storage changes were calculated from the groundwater level and the aquifer porosity calculated from soil boring samples collected at the time of sensor installation. Except for differences noted here, the equipment and procedures used at the woodland site, as described by Landon and others (2009), also were used in this study at both the woodland and the grassland site.

Noticeably absent from equation 4 is the inflow and outflow of surface water from the footprint. This is continued from the earlier study by Landon and others (2009) and assumes that no surface water enters the footprint from upgradient sources and that all precipitation infiltrates into the flat and sandy soil of the sites. However, for 4 days during the 2008 flood there was surface flow within the footprint of both study sites. It is likely that most of the surface water that flowed into the footprint area also flowed out of it. However, a net loss of surface water within the footprint area would lead to the underestimation of groundwater recharge, and a net gain of surface water would have the opposite effect. In addition, all precipitation that fell at the sites during this unique time period of exceptional conditions $(20.2 \mathrm{~mm}$ at the woodland site, $28.1 \mathrm{~mm}$ at the grassland site) was assumed to have become runoff and, therefore, was not included in the precipitation term when calculating the water balance.

With the eddy-covariance footprints expanding beyond the vegetation communities of interest, any ET originating from beyond the target vegetation area would bias the water balance calculations toward a higher value of $G W_{\text {in }}-G W_{\text {out }}$ and indicate more groundwater use than the system actually experienced.

\section{Additional Explanatory Variables}

Several other parameters, such as precipitation and soilwater content, were either measured or calculated for use in data analysis. Methods of data collection and calculation for these parameters are detailed in the following sections.

\section{Precipitation}

Two tipping-bucket rain gages were used to measure precipitation at each site, one model TE525 (Campbell Scientific, Inc., Logan, Utah) and one model TB4 (Hydrological Services, Sydney, Australia). At the woodland site, the TE525 was mounted on the tower at a height of approximately $20.5 \mathrm{~m}$, whereas the TB4 was mounted on the ground in an open meadow. At the grassland site, the TE525 was mounted at a height of approximately $1 \mathrm{~m}$, and the TB4 was mounted at an approximate height of $0.5 \mathrm{~m}$. The highest daily precipitation total from the two gages was the record for that day. On days where there were no good data from either gage (due to clogging, equipment problems, or freezing temperatures), daily precipitation data from local weather stations (National Climatic Data Center, 2012) were used for the record. The weather stations at Kearney and Holdrege (fig. 1) were selected as the closest available locations to the woodland site (approximately $19 \mathrm{~km}$ ) and the grassland site (approximately $28 \mathrm{~km}$ ), respectively.

Measured precipitation data were adjusted to account for systematic measurement errors. Following Larson and Peck (1974), data were adjusted to account for a negative bias because of increased turbulence caused by the wind blowing around the rain gages. Periodically, the rain gages were tested to ensure the calibration of the gages. Throughout the course of the study the rain gages were tested at least annually by slowly introducing a known amount of water to the gages. The gages showed a slightly positive bias during the tests, with readings ranging from 100 to 115 percent of the test volumes, with an average of 108 percent. To correct for this positive bias, the daily readings from each rain gage were scaled by dividing by the average bias from the tests of that gage. 


\section{Soil-Water Content}

At the grassland site, the volumetric soil-water content in the unsaturated zone (UZ) was measured every 30 minutes by two vertical arrays of water-content reflectometers (Campbell Scientific, Inc., models CS616 and CS615). The west array (UZW) was located under an area dominated by Kentucky bluegrass and reflectometers measured soil-water content at depths of 4, 37, 60, and $100 \mathrm{~cm}$ below the land surface. The east array (UZE) was located under an area dominated by taller vegetation (predominantly prairie cordgrass) and had reflectometers at depths of $4,37,81$, and $120 \mathrm{~cm}$ below the land surface.

Volumetric soil-water time-series data were finalized after adjustment to filter the field measured values using a laboratory-based porosity value. During the course of the study, five sets of soil samples were collected near the reflectometers and at corresponding depths. These samples were analyzed for bulk density and gravimetric moisture content, from which volumetric water content and porosity were calculated. The corresponding reflectometer data were then adjusted based on linear regression to better agree with the sample results. The porosity of the soil was the average value calculated from the bulk density samples collected and analyzed in the laboratory (Ward Laboratories, Inc., Kearney, Nebr.). Using these porosities, it was clear when the reflectometer data were producing anomalously high results, often associated with saturated soils. If a reflectometer reading was greater than the calculated porosity, then the porosity was used as the saturated water content at that time.

\section{Available Water Content}

In addition to their use to calculate the change in vadosezone water storage, the reflectometer data were used in conjunction with groundwater levels to compute the amount of water in the soil within the plant root zone at both study sites. It was postulated that a single metric incorporating available water in the vadose zone and in the groundwater might explain ET fluctuations. This metric was computed as the amount of water within a control volume. The control volume matched the footprint area, and an arbitrary bottom to the volume was set at a depth of $1.5 \mathrm{~m}$ below land surface. This datum was just below the minimum level of the groundwater table for the study period, so any phreatophytic vegetation with roots deeper than $1.5 \mathrm{~m}$ would experience uniform water availability. The available water content (expressed as a volume of water per unit area, cubic meter per square meter $\left(\mathrm{m}^{3} / \mathrm{m}^{2}\right)$, simplifying to a depth of water, in meters, in the $1.5-\mathrm{m}$ control volume) was calculated by integrating the incremental soilwater content of the entire $1.5 \mathrm{-m}$ profile using the reflectometer readings, spacing, and groundwater level. When the water level was above land surface, the depth of surface water was added to the water content of the soil. It is recognized that not all of this soil water would be physiologically available to plants, but the metric was used as a possible explanatory variable to help describe the ET patterns and timing observed.

\section{Evapotranspiration Modeling}

To provide a method for using the results of the study beyond the site footprints, crop coefficients were developed for the grassland site using the methods and data sources detailed by Landon and others (2009). Additionally, the crop coefficients developed by Landon and others (2009) for the woodland site were applied to data from that site for the current study period to validate their accuracy.

\section{Statistical Analysis}

Statistical analyses, including simple and multiple linear regressions (SLR and MLR, respectively) were calculated following the procedures outlined by Landon and others (2009). Spotfire S+ software, version 8.1 (TIBCO Software, Inc., 2008) was used for analysis. Differences between data groups were calculated using t-tests using a significance level $(p)$ threshold of 5 percent to determine statistical significance $(p<0.05)$.

\section{Estimating Evapotranspiration from Diel Groundwater Variations}

Attempts were made to calculate evapotranspiration from diel groundwater fluctuations (White, 1932; Healy and Cook, 2002). Not only could these diel groundwater fluctuations be used for further validation of the ET estimates from the flux towers, but they also would be informative for identifying the fraction of ET originating from groundwater sources rather than vadose-zone water. Unfortunately, management of the river system during this study period introduced a diel fluctuation in the nearby surface water. As a result, ET-induced fluctuations in the local water table could not be confidently distinguished from fluctuations caused by the river.

\section{Water Consumption Rates}

Evapotranspiration rates for the riparian woodland near Odessa and the riparian grassland near Elm Creek are summarized for the 3-year study period that comprised calendar years 2008-09 and 2011. A validation of the ET data is detailed before summarizing additional data regarding precipitation and soil moisture. An annual water balance for both study sites is detailed before an analysis of crop coefficients is presented. Daily values for all data are tabulated for the riparian woodland in appendix 1 and the riparian grassland in appendix 2 . 


\section{Eddy-Covariance Data}

A number of evaluations were used to ensure the quality and accuracy of the ET data obtained in this study. Several quality-assurance methods were used, including comparison of the eddy-covariance data with an energy balance and installation of a second eddy-covariance sensor to directly compare flux measurements. This evaluation focuses on the data from the woodland site, where direct measurement of ET was successful for the entire study period.

\section{Energy Balance}

Landon and others (2009) reported an average annual EBR of 0.89 and discussed theory and justification for the annual EBR being typically between 0.7 and 1.0. About twothirds (25 of 36) of monthly EBR values fell within the range of 0.85 to 1.05 (table 1). For the 3 -year period at the woodland site for this study, the average annual EBR was 0.923 , with a range of 0.905 to 0.940 . This was considered an indication that high confidence could be placed in the eddy-covariance flux data obtained from the installation.

\section{Direct Water Vapor Flux Comparison}

The installation late in 2011 of an infrared gas analyzer (IGA) to measure water vapor flux allowed for direct comparison and verification of the accuracy of the data obtained from the krypton hygrometer that was operated for the entire study at the woodland site. The two sensors were operational and recording data for the last 101 days of the study period, which equated to the end of the growing season and the beginning of the nongrowing season. Total ET measured using data from the IGA during this 101-day period was $86.3 \mathrm{~mm}$, or 102 percent of the ET recorded from the krypton hygrometer, with a median daily value that was 108 percent of the median daily ET based on the krypton hygrometer. Only during the first 49 days of the overlapping sensor deployment did the ET exceed $1 \mathrm{~mm} /$ day, and during this time (considered more representative of the growing season) the median of the daily IGA ET measurements was 101 percent of the original sensor measurements. The EBR for this 101-day period using data from the original sensor was 0.89 , and the EBR from the IGA data was 0.85 . When data collected at a $10-\mathrm{Hz}$ frequency from the IGA were processed and summed in 30-minute time periods, the data indicated a nearly perfect agreement with the standard processing of the 30-minute average data from the same sensor; however, there was a slight bias when $10-\mathrm{Hz}$ data were compared to the krypton hygrometer data, with the $10-\mathrm{Hz}$ data averaging nearly $0.1 \mathrm{~mm}$ per day higher ET. The joint deployment of the sensors and the overall agreement between the measurements further confirmed the reliable operation of the long-term sensor and added confidence in the quality of the ET measurements.

\section{Evapotranspiration Rates}

Evapotranspiration was totaled on daily, monthly, and annual time frames (fig. 6). In general, ET was lower at the grassland site than at the woodland site. However, there were differences between the sites in the timing of the ET.

In each of the 3 years of the study, the annual ET at the grassland site was about 90 percent of the annual ET measured at the woodland site, with averages of $653 \mathrm{~mm}$ and $726 \mathrm{~mm}$, respectively (figs. $6 C$ and $6 F$ ). The annual ET ranges observed throughout this study were from 585 to $711 \mathrm{~mm}$ at the grassland site and from 669 to $775 \mathrm{~mm}$ at the woodland site (table 2). Though consistent on an annual basis, the intersite differences were more variable on a daily and monthly basis. The maximum daily ET at the woodland site was $9.3 \mathrm{~mm}$, whereas the grassland site only experienced a maximum daily ET of $6.7 \mathrm{~mm}$ during the 3 years of the study.

\section{Differences in Seasonal Evapotranspiration Rates}

Monthly ET results revealed seasonal patterns differing between the two vegetation communities. There was no significant intersite difference in the nongrowing season (November-March) mean monthly ET of $10.4 \mathrm{~mm}(p=0.08)$. During the transition seasons of spring (April-May) and fall (September-October), ET averaged $58.7 \mathrm{~mm} / \mathrm{month}$ overall, with the grassland site $(60.3 \mathrm{~mm} / \mathrm{month})$ reporting slightly higher (but not significantly different) ET than the woodland site $(57.0 \mathrm{~mm} /$ month $)(p=0.11)$. For summer's peak growing months (June-August), ET averaged $134 \mathrm{~mm} /$ month overall, with ET at the woodland site eclipsing the grassland site with approximately $25.1 \mathrm{~mm} / \mathrm{month}$, or 21 percent, more ET ( $p=$ $0.0003)$. As with the daily totals, peak monthly totals were always measured during the month of July and were higher at the woodland site than at the grassland site, with peak ET of $191 \mathrm{~mm}$ and $140 \mathrm{~mm}$, respectively.

The difference in the observed seasonal pattern in ET is likely a result of the plant community being monitored at each site. As was reported by Landon and others (2009), the riparian woodland near Odessa typically experienced rapid leaf growth during the month of May and did not reach peak leaf coverage until July or August. This matches well with the ET pattern observed at the woodland site during this study and contrasts with the growing pattern of the vegetation at the grassland study. The predominant grass species at the grassland site, Kentucky bluegrass, is a cool-season grass with shallow roots that begins growth early in the spring, can have a dormant period during the heat of summer, and has another growth period in the fall (U.S. Department of Agriculture, 2013). These growth-pattern differences help to explain the observed ET patterns, with the grassland site having ET rates similar to the woodland site during the spring and fall but lower ET rates during the summer. 
Table 1. Summary of monthly mean energy fluxes for riparian woodland and grassland study sites near Odessa and Elm Creek, Nebraska, respectively, 2008-09 and 2011.

$\left[\mathrm{R}_{\mathrm{n}}\right.$, net radiation; $\mathrm{W} / \mathrm{m}^{2}$, watts per square meter; $\lambda \mathrm{E}$, latent-heat flux; $\mathrm{H}$, sensible-heat flux; $\mathrm{G}$, soil-heat flux; EBR, energy-balance ratio (equation 2)]

\begin{tabular}{|c|c|c|c|c|c|c|c|c|c|c|}
\hline \multirow[b]{2}{*}{ Month } & \multirow[b]{2}{*}{ Year } & \multicolumn{5}{|c|}{ Woodland } & \multicolumn{4}{|c|}{ Grassland } \\
\hline & & $\begin{array}{l}\text { Monthly } \\
\text { mean } R_{n} \\
\left(W / m^{2}\right)\end{array}$ & $\begin{array}{c}\text { Monthly } \\
\text { mean } \lambda E \\
\left(W / m^{2}\right)\end{array}$ & $\begin{array}{c}\text { Monthly } \\
\text { mean H } \\
\left(\mathrm{W} / \mathrm{m}^{2}\right)\end{array}$ & $\begin{array}{c}\text { Monthly } \\
\text { mean G } \\
\left(\mathrm{W} / \mathrm{m}^{2}\right)\end{array}$ & $\begin{array}{c}\text { Monthly } \\
\text { mean EBR } \\
\text { (dimensionless) }\end{array}$ & $\begin{array}{l}\text { Monthly } \\
\text { mean } R_{n} \\
\left(W / m^{2}\right)\end{array}$ & $\begin{array}{c}\text { Monthly } \\
\text { mean } \lambda E \\
\left(W / m^{2}\right)\end{array}$ & $\begin{array}{c}\text { Monthly } \\
\text { mean H } \\
\left(\mathrm{W} / \mathrm{m}^{2}\right)\end{array}$ & $\begin{array}{c}\text { Monthly } \\
\text { mean G } \\
\left(\mathrm{W} / \mathrm{m}^{2}\right)\end{array}$ \\
\hline January & 2008 & 8.84 & 5.47 & 13.20 & -7.75 & 1.34 & -11.34 & -8.55 & -0.46 & -6.26 \\
\hline February & 2008 & 40.89 & 10.66 & 39.90 & -4.75 & 1.24 & 31.76 & 10.00 & 32.30 & -4.21 \\
\hline March & 2008 & 71.44 & 15.87 & 62.84 & 0.05 & 1.15 & 53.23 & 12.67 & 50.68 & 1.01 \\
\hline May & 2008 & 123.76 & 77.60 & 47.35 & 6.53 & 0.97 & 97.47 & 86.39 & 31.70 & 8.89 \\
\hline June & 2008 & 172.14 & 151.89 & 27.83 & 7.68 & 0.97 & 133.41 & 143.37 & 24.75 & 8.47 \\
\hline July & 2008 & 172.74 & 155.62 & 23.35 & 7.26 & 1.02 & 135.29 & 141.52 & 29.28 & 7.65 \\
\hline August & 2008 & 137.75 & 126.88 & 18.13 & 3.29 & 0.95 & 109.79 & 121.13 & 21.53 & 2.48 \\
\hline December & 2008 & 2.12 & 5.97 & 5.03 & -8.47 & 1.35 & -1.01 & 2.26 & 3.94 & -8.15 \\
\hline January & 2009 & 11.05 & 9.50 & 7.92 & -6.33 & 0.86 & 4.69 & 7.47 & 4.46 & -6.25 \\
\hline February & 2009 & 41.26 & 2.67 & 42.71 & -2.00 & 1.01 & 24.08 & 7.27 & 24.12 & -2.45 \\
\hline March & 2009 & 73.32 & 11.77 & 68.97 & 0.60 & 1.16 & 47.93 & 17.33 & 42.14 & -1.00 \\
\hline April & 2009 & 108.41 & 35.13 & 78.65 & 5.65 & 1.16 & 76.19 & 46.07 & 44.85 & 5.34 \\
\hline May & 2009 & 140.62 & 85.02 & 58.41 & 7.63 & 1.03 & 102.30 & 99.10 & 28.25 & 6.67 \\
\hline June & 2009 & 147.39 & 129.62 & 21.34 & 7.58 & 0.96 & 111.36 & 111.78 & 27.04 & 7.62 \\
\hline July & 2009 & 165.33 & 143.05 & 28.55 & 5.36 & 0.91 & 125.64 & 119.49 & 40.34 & 3.91 \\
\hline August & 2009 & 155.56 & 127.00 & 35.83 & 3.54 & 0.95 & 119.73 & 107.13 & 45.57 & 2.28 \\
\hline March & 2011 & 62.45 & 15.50 & 50.41 & 0.16 & 1.02 & 38.72 & 22.10 & 27.18 & -1.01 \\
\hline April & 2011 & 94.17 & 35.91 & 65.57 & 3.74 & 1.20 & 73.28 & 55.11 & 36.56 & 1.90 \\
\hline May & 2011 & 119.27 & 66.28 & 55.85 & 6.34 & 1.05 & 93.33 & 95.47 & 21.93 & 5.44 \\
\hline June & 2011 & 155.63 & 145.65 & 14.62 & 8.04 & 0.97 & 119.46 & 146.39 & 6.83 & 7.20 \\
\hline July & 2011 & 167.94 & 175.96 & -2.42 & 7.88 & 1.05 & 128.76 & 146.07 & 16.00 & 9.55 \\
\hline August & 2011 & 147.11 & 138.32 & 15.30 & 3.52 & 0.86 & 112.12 & 123.35 & 19.50 & 5.76 \\
\hline September & 2011 & 104.24 & 82.87 & 29.64 & -1.91 & 0.91 & 78.07 & 78.73 & 22.96 & 0.38 \\
\hline October & 2011 & 66.64 & 39.86 & 35.64 & -4.37 & 1.00 & 47.76 & 51.69 & 14.19 & -3.45 \\
\hline November & 2011 & 32.38 & 15.54 & 25.48 & -7.48 & 0.96 & 15.04 & 12.58 & 11.50 & -5.47 \\
\hline December & 2011 & 17.83 & 12.94 & 11.46 & -6.39 & 0.78 & 2.22 & 8.16 & -0.07 & -5.08 \\
\hline Mean & & 85.58 & 58.98 & 33.23 & -0.19 & 1.03 & 62.20 & 58.03 & 22.76 & -0.13 \\
\hline
\end{tabular}



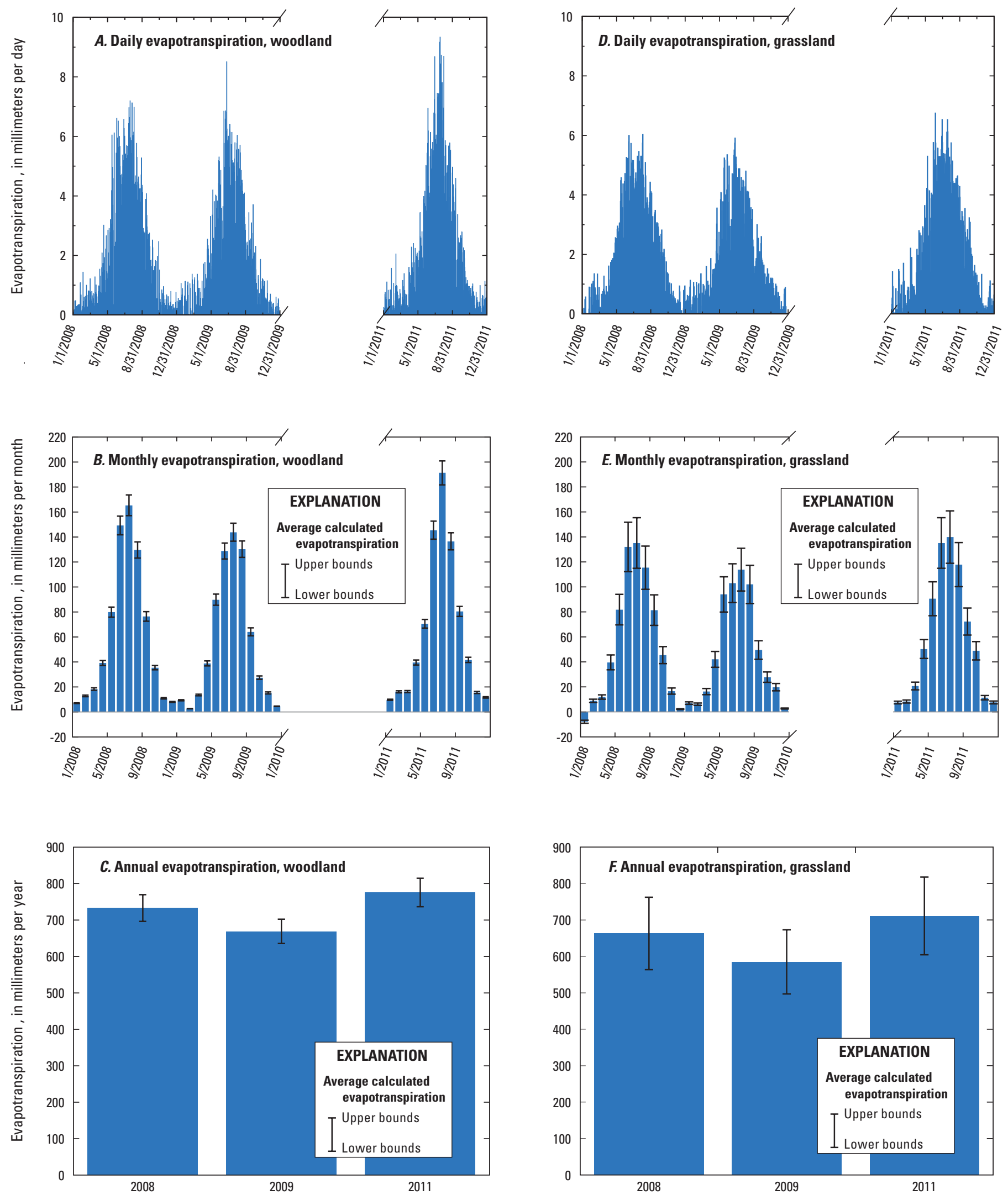

Figure 6. Daily, monthly, and annual evapotranspiration (ET) for $(A, B$, and $C)$ woodland and $(D, E$, and $F)$ grassland study sites near Odessa and Elm Creek, Nebraska, respectively, 2008-09 and 2011. Upper and lower bounds of ET calculations are indicated on monthly $(B$ and $E)$ and annual $(C$ and $F$ ) data. 


\section{Differences in Annual Evapotranspiration Rates}

The higher annual ET rates at the woodland site as compared to the grassland site may be the result of differences in many factors, including rooting depth, vegetation water use, albedo, and water availability. The dimensionless crop coefficient for cool-season turf grass peaks at 0.95 , whereas for deciduous apple trees with active ground cover it peaks at 1.20 (Allen and others, 1998). Of the various vegetation types under well-watered conditions for which crop coefficients were published, apple trees presumably were most similar to a riparian forest of cottonwood trees with a dogwood shrub understory. Although Landon and others (2009) developed crop coefficients for riparian forests, these were developed under water-limited conditions and were considerably lower than the values of Allen and others (1998).

Climatic disparities provided another important, and unexpected, explanation for ET differences between the sites. The two sites were chosen, in part, because of the proximity to one another (18.8 km apart). It was anticipated that this would minimize the climatic differences between the sites, thereby minimizing the inherent differences in turbulent fluxes resulting from these climatic factors. However, this was not the case. Climatic drivers of ET, such as vapor-pressure deficit, insolation, and air temperature, were significantly greater (based upon paired t-tests, $p<0.03$ for all tests) at the woodland site during the study. Vapor-pressure deficit - the difference between saturation vapor pressure and the atmospheric vapor pressure - is a measure of dryness. As vapor-pressure deficit increases, evaporative processes intensify. On average, the monthly vapor-pressure deficit was 9.4 percent larger at the woodland site than at the grassland site $(p<0.0001)$. Solar radiation is the primary source of energy in the study sites, and the monthly solar radiation was on average 9.2 percent higher at the woodland site than at the grassland site $(p<0.0001)$. Finally, hotter air temperatures would be expected to accelerate ET, and the woodland site averaged 0.4 degrees Celsius hotter than the grassland site $(p<0.0001)$. A direct result of these climatic differences was that the potential ET at the woodland site was 9.5 percent higher than at the grassland site $(p=0.003)$. These results help to explain the higher ET rates observed at the woodland site because there was more energy available in the local ecosystem and a drier air mass at the site. As a result, any conclusions drawn from the ET data need to consider that, climatically, the woodland site was predisposed to have higher ET rates.

The health of the vegetation also may have been a factor in the difference. In 2008 and 2011, both sites experienced very shallow water levels, and even submergence at times, within the footprint areas. Phreatophytic plants, such as cottonwoods and dogwoods endemic to the riparian forest, would likely thrive in these conditions; whereas, the riparian grasses may have been stressed by excessive soil water or flooding. The effects of grazing also affected vegetation health, introducing yet another explanatory factor affecting ET rates at the riparian grassland in 2008 and 2009. The overall effect of grazing may have been to reduce summer ET rates at the grassland site. However, it is conceivable that ET rates may have persisted later into the season at the grassland site as a result of regrowth of grasses following the grazing disturbance, similar to that seen by Bremer and others (2001) in Kansas.

\section{Precipitation}

Precipitation at both sites was highly variable throughout the course of the study on daily, monthly, and annual time frames. This variability helped to produce a wide range of hydrologic conditions, from periods of below-normal precipitation to periods of overbank river flooding. Although most of the precipitation events were less than $25 \mathrm{~mm}$, a maximum daily precipitation of greater than $84 \mathrm{~mm}$ was recorded at the grassland site.

A strong seasonal pattern is evident in the 30 -year monthly average precipitation data (climatic normals for 1981-2010, National Climatic Data Center, 2012) from the weather stations at Kearney and Overton (approximately $14 \mathrm{~km}$ from the grassland site), which were used as the normal precipitation at the woodland and grassland sites, respectively (fig. 7). Normal monthly precipitation is nearly identical for both sites and ranges from $12 \mathrm{~mm}$ to $106 \mathrm{~mm}$, with the months of May to September accounting for 65 percent of the annual total precipitation at both sites.

At both sites, the winter months of November through March experienced below-average precipitation for the entire study period. Both sites, along with the surrounding region, reported a wet May 2008 that led to flooding along the central Platte River. At the grassland site, the monthly precipitation continued to be well above normal through August 2008, for a span of 4 consecutive months, whereas the woodland site returned to nearly normal precipitation after the wet May. Both sites then experienced a drier than normal September before a wet October brought more than four times the normal monthly precipitation. For most of summer 2009 the precipitation at both sites was below normal, with the exception of the month of June at the woodland site, which was above normal. This drier summer was followed by a wetter than normal fall, with precipitation amounts for both September and October being much higher than normal. Precipitation in 2011 began near to slightly above normal and followed the normal pattern through June at both sites. August and October precipitation observations, which were wetter than normal, bracketed a drier than normal September.

Annual precipitation for the study period of 2008-09 and 2011 was near to above normal at both sites. Thirty-year average annual precipitation at the Kearney station for 1981-2010 was $640 \mathrm{~mm}$, whereas the Overton station averaged $636 \mathrm{~mm}$ of annual precipitation (National Climatic Data Center, 2012). Observed precipitation ranged from 602 to $836 \mathrm{~mm}$ at the woodland site, and from 580 to $989 \mathrm{~mm}$ at the grassland site (table 2). The wet year at both sites was 2008 , which was 



Figure 7. Daily, monthly measured and normal, and annual measured and normal precipitation for woodland and grassland study sites near Odessa and Elm Creek, Nebraska, respectively, 2008-09 and 2011. (Normal precipitation from National Climatic Data Center, 2012). 
driven by the much-above-average monthly precipitation in May and October discussed earlier. 2009 and 2011 were characterized by nearly normal precipitation totals that generally followed average timing.

\section{Available Water Content}

The available water content in the top $1.5 \mathrm{~m}$ of soil at the woodland site was calculated for all 7 years of data record (2002-05, 2008-09, 2011) and monthly averages are shown in figure 8 . Monthly average available water content values ranged from $0.102 \mathrm{~m}$ of water to $0.518 \mathrm{~m}$ of water, with an average monthly value of $0.257 \mathrm{~m}$ of water. Typically a seasonal pattern was evident in the soil moisture, with depletion in soil water evident during the later parts of the growing season as the flows in the Platte River decreased, leading to a falling water table, followed by a recharge of soil moisture during the nongrowing season. During 2011, soil-moisture conditions deviated from this pattern as flows in the Platte River were maintained at a consistently high level throughout most of the later growing season, providing abundant soil moisture to the riparian lands of the study areas.

The grassland site received the same seasonal and annual patterns in soil moisture that were observed at the woodland site but with less absolute variation. This was likely the result of the thick layer of fine material that maintained more consistent soil-moisture content than did the sandy soil at the woodland site. Monthly average available water content values in the top $1.5 \mathrm{~m}$ of soil ranged from $0.638 \mathrm{~m}$ of water to $0.777 \mathrm{~m}$ of water, with an average monthly value of $0.711 \mathrm{~m}$ of water.

\section{Water Balance}

Annual water balances were calculated for each site using equation 4 . At both sites, the predominant factors in the water balance were ET and precipitation. The annual water balance calculations indicated a similar pattern and magnitude in the annual groundwater-interaction components. Comparisons of the woodland-site water balance from this study to corresponding values from Landon and others (2009) indicated important differences between the differing time frames of the two studies.

\section{Differences in Water Balance between a Riparian Grassland and Woodland}

The amount of water stored either as groundwater or vadose-zone water varied more at the grassland site than at the woodland site. However, much of this can be attributed to

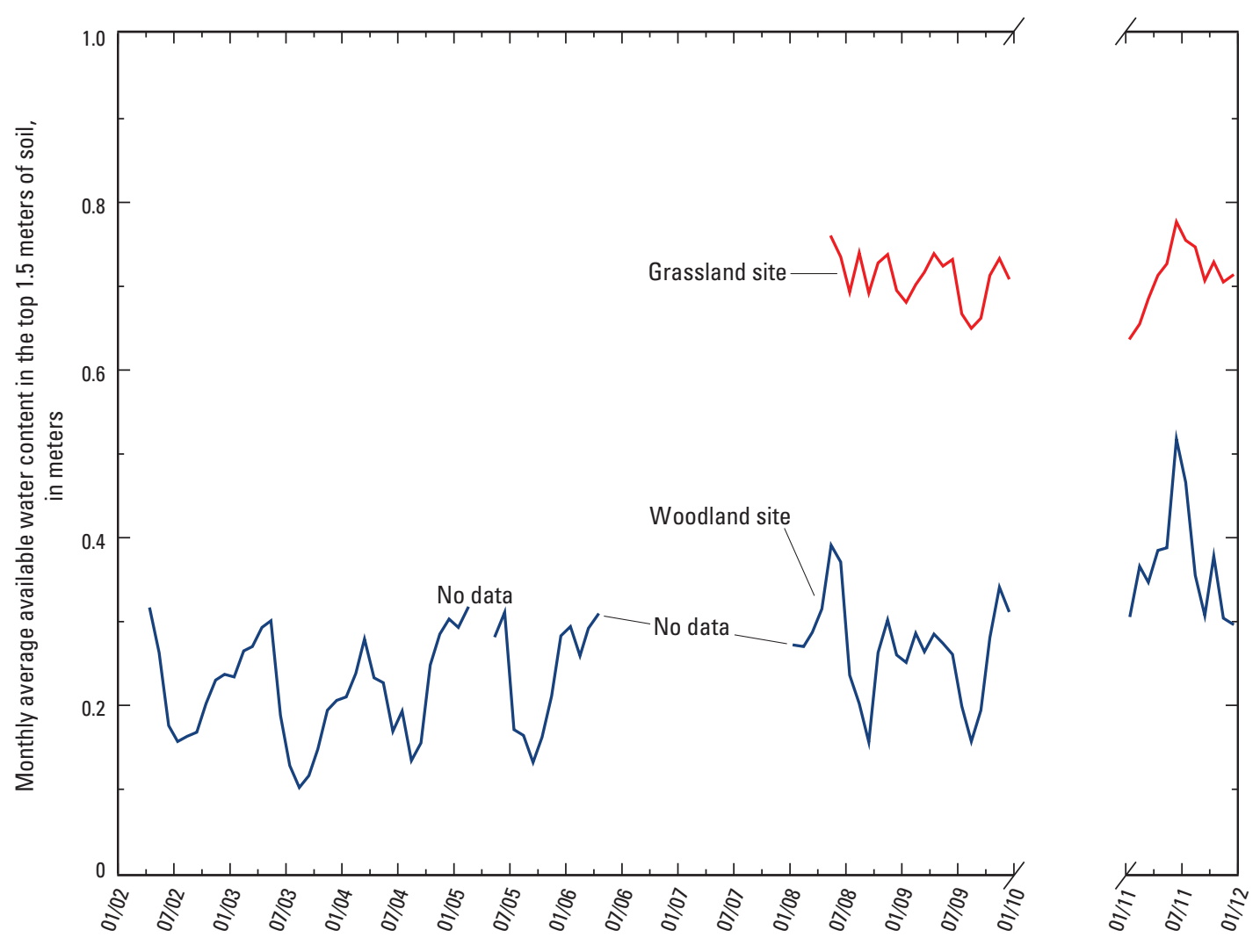

Figure 8. Monthly average available water content in the top $1.5 \mathrm{~m}$ of the soil profile at woodland and grassland study sites near Odessa and Elm Creek, Nebraska, respectively, 2002-05, 2008-09, and 2011. 
the reclassification of vadose-zone water to groundwater as a result of rising water levels from January 1 of one year to the next year. It also may reflect the greater capacity to store groundwater (as evidenced by higher porosity values) at the grassland site.

As indicated by figure 3, river levels adjacent to the study sites were higher than groundwater levels, and a loss of surface water into the groundwater system was the likely result of this hydraulic gradient. In the context of the annual water balance within the control volume of the study sites, this influx of surface water would have increased the amount of water available to plants beyond that supplied by precipitation if root depths were sufficient to access that water. Therefore, ET at the sites would more likely be energy-limited than waterlimited, making the sites prone to a net loss of groundwater (as indicated by positive values of $G W_{\text {in }}-G W_{\text {out }}$ in equation 4 and table 2) unless exceptionally high precipitation also fell during the period. In fact, this was generally the trend at the woodland site, with measured groundwater losses in 2009 and 2011, but groundwater recharge in 2008, in which above-average precipitation was measured (table 2). On average, there was a 64-mm loss of groundwater from the woodland site during the study, whereas groundwater recharge was averaging $48 \mathrm{~mm}$ at the grassland site.

Although ET rates may not have been limited by the amount of precipitation, the amount of groundwater loss or recharge was strongly affected by the disparity between precipitation and ET for a given year (fig. 9B). During 2008 both sites experience a surplus of precipitation compared to ET and average precipitation, leading to a net groundwater recharge of 124 and $322 \mathrm{~mm}$ at the woodland and grassland sites, respectively (table 2). There was a deficit in precipitation compared to ET at both sites in 2009 and 2011, leading to a net groundwater use of greater than $140 \mathrm{~mm}$ per year at the woodland site and greater than $55 \mathrm{~mm}$ per year at the grassland site, thus indicating that the determination of annual groundwater use or recharge depends predominantly upon the relation between the ET and precipitation in these riparian areas with shallow soil layers above the groundwater table.

\section{Riparian Woodland Water Balance, 2002-11}

The monitoring of Landon and others (2009) made available four additional annual water balances dating back to 2002 for comparison to this study period at the woodland site. Perhaps most striking in this comparison was the increase in annual ET for 2008-09 and 2011 despite precipitation totals and potential ET rates that were within the range of those monitored in 2002-05 (fig. 9A). This increase in ET was responsible for a corresponding increase in groundwater usage, resulting in groundwater discharge in 2 of 3 years (table 2, fig. 9B). There are likely two primary reasons for the increase in ET. First, the woodland vegetation health likely was improved in 2008-09 and 2011 as compared to the drought-affected years of 2002-05, as evidenced by increases in peak LAI, as described in Vegetation Characteristics. In addition, groundwater levels were higher in 2008-09 and 2011 than they were in 2002-05, reducing the effects of water limitation on the plants.

\section{Simulation of Evapotranspiration Rates}

The accuracy of the monthly crop coefficients $\left(k_{\mathrm{c}}\right)$ developed for the woodland site by Landon and others (2009) was assessed in comparison to the measured ET rates from 2008-09 and 2011. Using reference ET data for the nearby weather station at Kearney, Nebraska (High Plains Regional Climate Center, 2012) daily ET was simulated for the study period. Total simulated ET was compared to ET measured monthly and annually (fig. 10, table 3). Overall the simulated ET was lower than measured ET for the entire growing season and only averaged 65 percent of annual measured ET for the 3 years of the study. Simulated monthly ET values were especially low during the peak ET months of June-August. New monthly crop coefficients incorporating all 7 years of record were calculated for the woodland site, producing nearly identical $k_{\mathrm{c}}$ values for October through May and higher $k_{\mathrm{c}}$ values for June through September.

Monthly crop coefficients also were developed for riparian grasslands using the ET values from 2008-09 and 2011 at the grassland site (table 3). The $k_{\mathrm{c}}$ values developed for the grassland site were similar to the $k_{\mathrm{c}}$ values for the woodland site during the same time period.

A comparison of the weather station reference ET and the measured ET data for all 7 years of the woodland-site record indicates that although the average reference ET was higher in 2002-05 than in 2008-09 and 2011, the average measured ET was lower in 2002-05 during crop coefficient development because of water limitation and the resulting effect on plant health. This relation necessarily would cause the crop coefficients to underestimate ET when applied to periods similar to 2008-09 and 2011 having less water limitation and improved plant health. One possible metric for quantifying these water limitations is the vadose-zone water content. The lower soil-water content in 2002-05 may have restricted ET. The application of a soil-moisture stress term in the crop coefficient equation (Jensen and others, 1971; Allen and others, 2005) may be a better solution to assigning a riparianwoodland crop coefficient than recalculating new $k_{\mathrm{c}}$ values that simply average the wet and dry conditions experienced during the 7 years of study. This underestimation of ET and the possible reasons suggest that soil-moisture stress is an important factor to consider when using crop coefficients to simulate ET in areas without natural or managed consistency in soil moisture, even in riparian areas or other regions with a shallow water table and phreatophytic vegetation. Moreover, the crop coefficient is, by design, meant to predict ET rates for a given crop, or species, of plant. By representing an entire plant community within one coefficient, the effectiveness of that coefficient is diminished both over time (as a result of plant succession) and spatially (as a result of spatial variations in plant communities). 


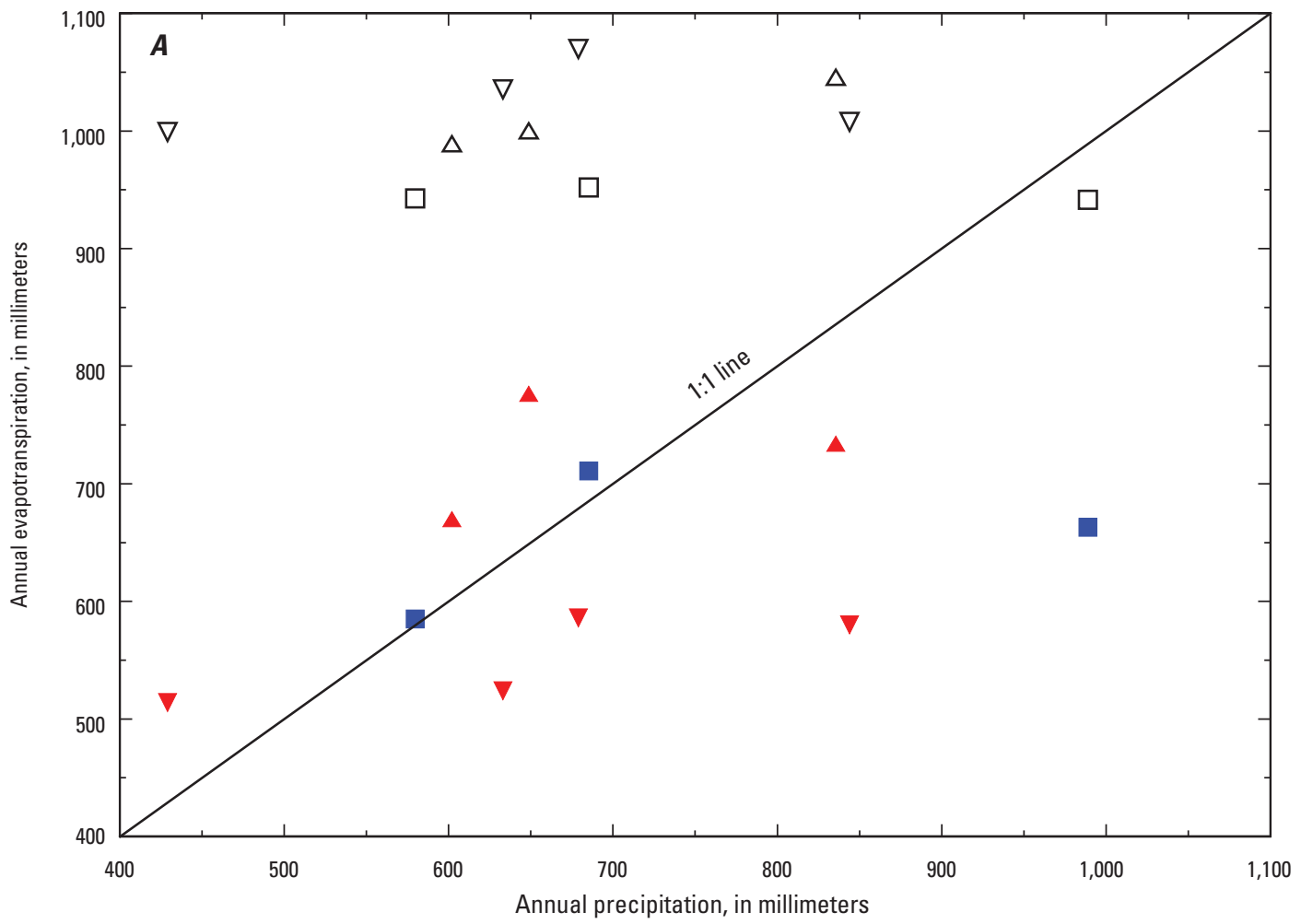

EXPLANATION

Evapotranspiration

Measured

A Woodland 2008-11

Grassland 2008-11

$\checkmark$ Woodland 2002-05

Potential

$\triangle$ Woodland 2008-11

$\square$ Grassland 2008-11

$\nabla$ Woodland 2002-05

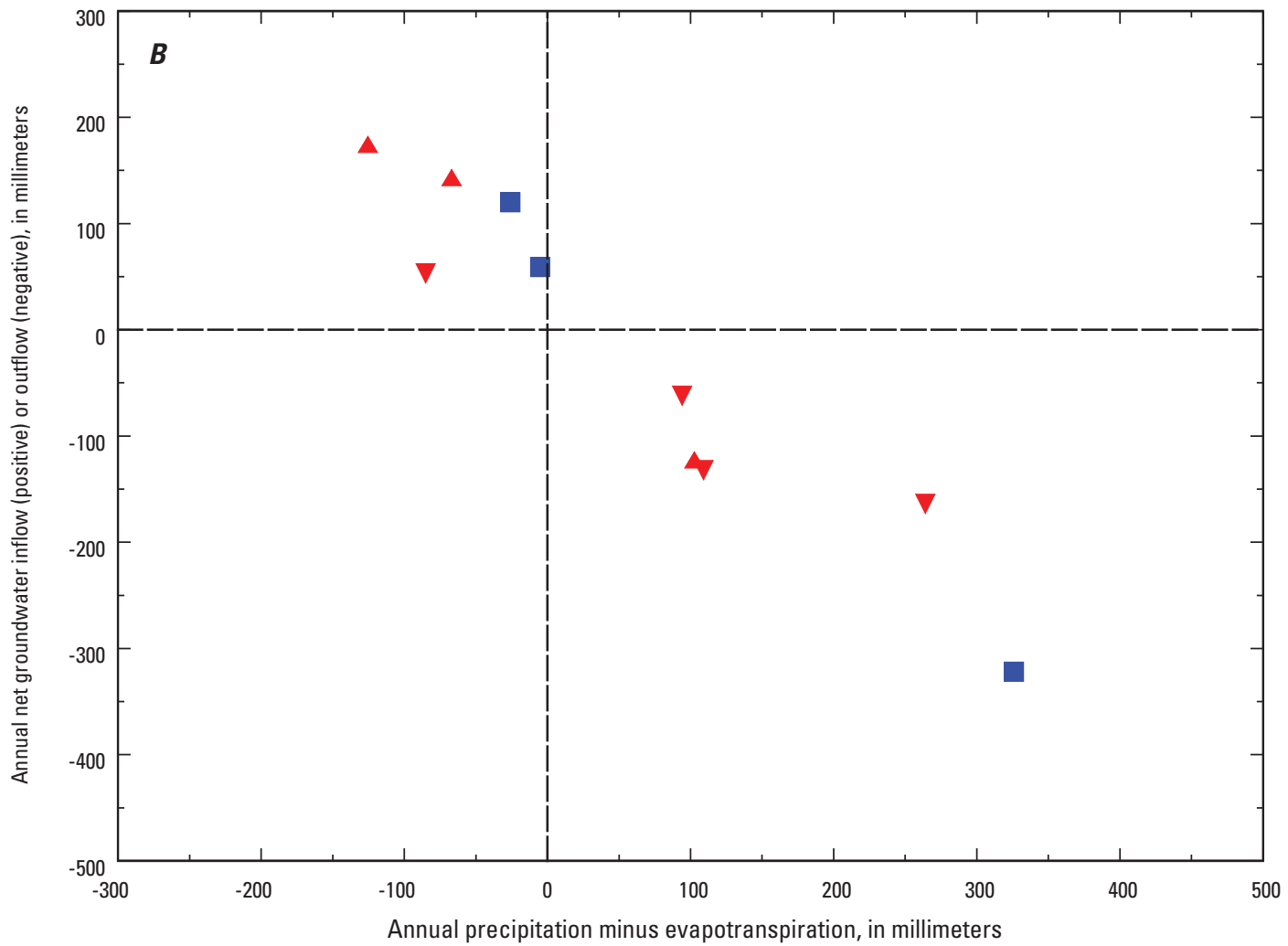

EXPLANATION

A Woodland 2008-11

Grassland 2008-11

$\checkmark$ Woodland 2002-05

Figure 9. Relations among annual water balance terms for riparian woodland and grassland study sites near Odessa and Elm Creek, Nebraska, respectively, 2002-05, 2008-09, and 2011. 


\section{Comparison of Water Consumption in Two Riparian Vegetation Communities along the Central Platte River, Nebraska}

Table 2. Annual water balance for a riparian woodland site near Odessa, Nebr., 2002-05, 2008-09, and 2011; and for a grassland site near Elm Creek, Nebr., 2008-09 and 2011.

[ET, total evapotranspiration; mm, millimeter; P, precipitation; P - ET, precipitation less total evapotranspiration; $\Delta$ VZW, change in vadose-zone-water storage; $\Delta \mathrm{GW}$, change in groundwater storage; $\Delta$ subsurfaceW, change in subsurface water (sum of $\Delta \mathrm{VZW}$ and $\Delta \mathrm{GW}$ ); $\mathrm{GW}_{\text {in }}-\mathrm{GW}_{\text {out }}$, difference between groundwater inflow and groundwater outflow to representative control volume (equation 4); --, no data]

\begin{tabular}{|c|c|c|c|c|c|c|c|}
\hline Year & $\begin{array}{c}\text { ET } \\
(\mathrm{mm})\end{array}$ & $\begin{array}{c}\mathbf{P} \\
(\mathrm{mm})\end{array}$ & $\begin{array}{c}P-E T \\
(m m)\end{array}$ & $\begin{array}{c}\Delta V Z W \\
(\mathrm{~mm})\end{array}$ & $\begin{array}{l}\Delta \mathrm{GW} \\
(\mathrm{mm})\end{array}$ & $\begin{array}{c}\Delta \text { subsurfaceW } \\
(\mathrm{mm})\end{array}$ & $\begin{array}{c}\mathbf{G W}_{\text {in }}-\mathbf{G W} \text { out } \\
(\mathrm{mm})\end{array}$ \\
\hline \multicolumn{8}{|c|}{ Woodland, 2002-05 } \\
\hline 2003 & 524 & 633 & 109 & 5 & -28 & -23 & -132 \\
\hline 2004 & 580 & 844 & 264 & 40 & 60 & 100 & -164 \\
\hline 4-year mean & 551 & 646 & -- & 5 & 14 & -- & -76 \\
\hline \multicolumn{8}{|c|}{ Woodland, 2008-09 and 2011} \\
\hline 2008 & 733 & 836 & 103 & 4 & -25 & -21 & -124 \\
\hline 2009 & 669 & 602 & -67 & 27 & 48 & 75 & 142 \\
\hline 2011 & 775 & 649 & -126 & 44 & 3 & 47 & 173 \\
\hline 2008 & 663 & 989 & 326 & -119 & 123 & 4 & -322 \\
\hline 2009 & 585 & 580 & -5 & -173 & 227 & 54 & 59 \\
\hline 2011 & 711 & 685 & -26 & 56 & 38 & 94 & 120 \\
\hline 3-year mean & 653 & 751 & -- & -79 & 129 & -- & -48 \\
\hline
\end{tabular}

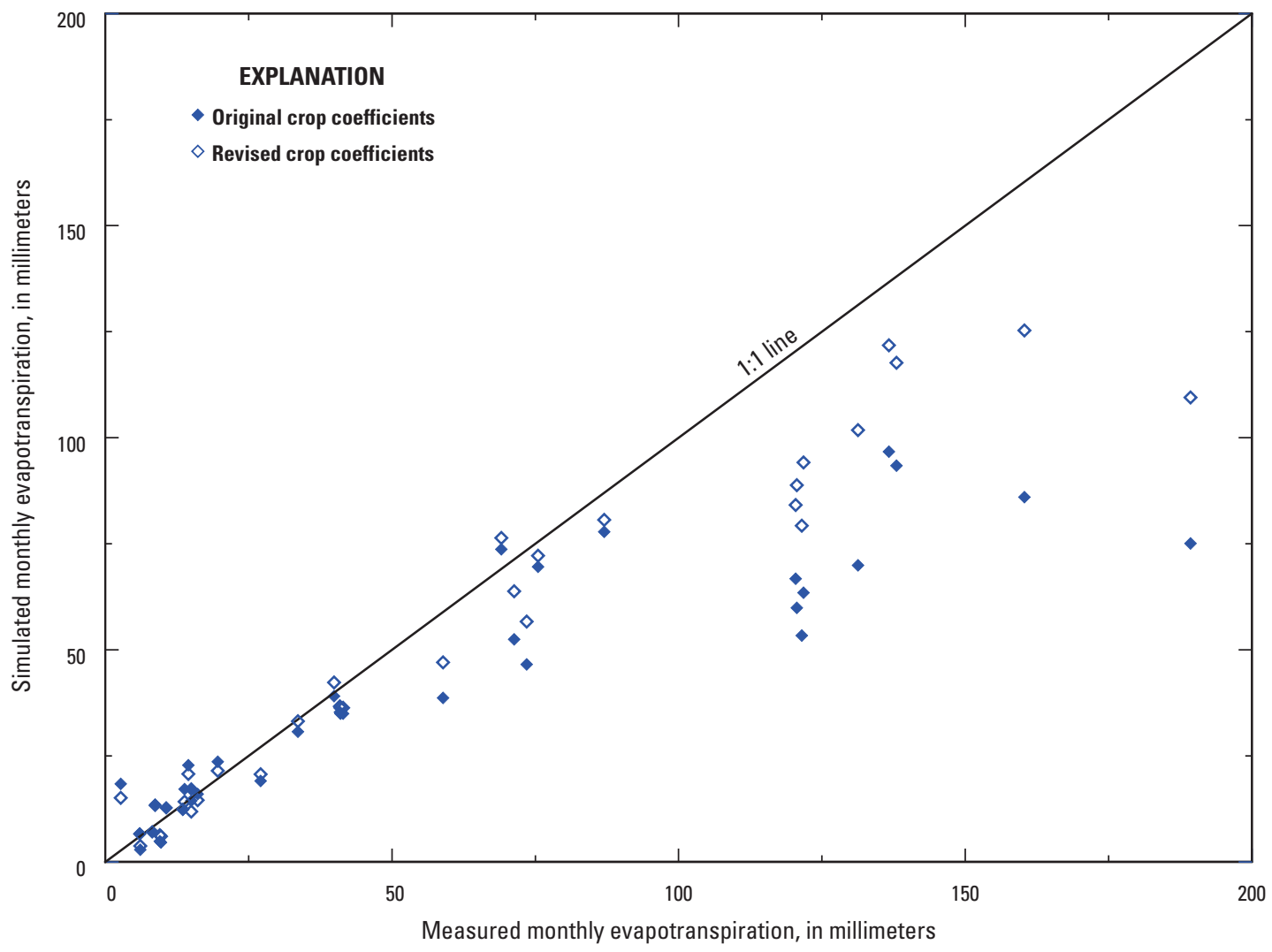

Figure 10. Relation of measured and simulated monthly evapotranspiration rates at a riparian woodland study site near Odessa, Nebraska, 2008-09 and 2011. Original crop coefficients from Landon and others (2009). 
Table 3. Average monthly crop coefficients for a riparian woodland study site near Odessa, Nebr., based on data from 2002-05, 2008-09, and 2011; and for a grassland study site near Elm Creek, Nebr., based on data from 2008-09 and 2011.

[ET, measured evapotranspiration at riparian study site; $\mathrm{mm} / \mathrm{d}$, millimeters per day; ET, evapotranspiration for well-watered alfalfa reference crop; $\mathrm{k}_{\mathrm{c}}$, crop coefficient determined as $\left.\mathrm{ET}_{/} \mathrm{ET}_{0}\right]$

\begin{tabular}{|c|c|c|c|c|c|c|c|c|c|c|c|c|}
\hline \multirow{3}{*}{$\begin{array}{c}\text { Evaluation } \\
\text { period }\end{array}$} & \multicolumn{9}{|c|}{ Woodland } & \multirow{2}{*}{\multicolumn{3}{|c|}{$\begin{array}{c}\text { Grassland } \\
2008-09 \text { and } 2011 \\
\end{array}$}} \\
\hline & \multicolumn{3}{|c|}{ 2002-05 } & \multicolumn{3}{|c|}{ 2008-09 and 2011} & \multicolumn{3}{|c|}{ 2002-05, 2008-09, and 2011} & & & \\
\hline & $\begin{array}{c}\text { Mean } \\
\text { ET } \\
(\mathrm{mm} / \mathrm{d})\end{array}$ & $\begin{array}{c}\text { Mean } \\
\text { ET }_{0} \\
(\mathrm{~mm} / \mathrm{d})^{1}\end{array}$ & $\begin{array}{c}\mathbf{k}_{\mathrm{c}} \\
\text { (dimen- } \\
\text { sionless) }\end{array}$ & $\begin{array}{c}\text { Mean } \\
\text { ET } \\
(\mathrm{mm} / \mathrm{d})\end{array}$ & $\begin{array}{c}\text { Mean } \\
\text { ET }_{0} \\
(\mathrm{~mm} / \mathrm{d})^{1}\end{array}$ & $\begin{array}{c}\mathbf{k}_{\mathrm{c}} \\
\text { (dimen- } \\
\text { sionless) }\end{array}$ & $\begin{array}{c}\text { Mean } \\
\text { ET } \\
(\mathrm{mm} / \mathrm{d})\end{array}$ & $\begin{array}{c}\text { Mean } \\
\text { ET }_{0} \\
(\mathrm{~mm} / \mathrm{d})^{1}\end{array}$ & $\begin{array}{c}\mathbf{k}_{\mathrm{c}} \\
\text { (dimen- } \\
\text { sionless) }\end{array}$ & $\begin{array}{c}\text { Mean } \\
\text { ET } \\
(\mathrm{mm} / \mathrm{d})\end{array}$ & $\begin{array}{c}\text { Mean } \\
\text { ET }_{0} \\
(\mathrm{~mm} / \mathrm{d})^{1}\end{array}$ & $\begin{array}{c}\mathbf{k}_{\mathrm{c}} \\
\text { (dimen- } \\
\text { sionless) }\end{array}$ \\
\hline January & 0.27 & 1.41 & 0.19 & 0.28 & 1.55 & 0.18 & 0.27 & 1.47 & 0.19 & 0.07 & 1.55 & 0.05 \\
\hline February & 0.47 & 1.87 & 0.25 & 0.38 & 2.38 & 0.16 & 0.43 & 2.09 & 0.21 & 0.27 & 2.35 & 0.12 \\
\hline April & 1.28 & 5.91 & 0.22 & 1.31 & 5.32 & 0.25 & 1.29 & 5.66 & 0.23 & 1.47 & 5.32 & 0.28 \\
\hline May & 2.51 & 6.60 & 0.38 & 2.59 & 6.26 & 0.41 & 2.54 & 6.45 & 0.39 & 2.87 & 6.26 & 0.46 \\
\hline June & 3.22 & 7.66 & 0.42 & 4.71 & 6.80 & 0.69 & 3.86 & 7.29 & 0.53 & 4.12 & 6.80 & 0.61 \\
\hline July & 2.99 & 7.79 & 0.38 & 5.38 & 6.54 & 0.82 & 4.02 & 7.25 & 0.55 & 4.18 & 6.54 & 0.64 \\
\hline November & 0.45 & 2.45 & 0.18 & 0.46 & 2.60 & 0.18 & 0.46 & 2.51 & 0.18 & 0.53 & 2.60 & 0.20 \\
\hline December & 0.22 & 2.01 & 0.11 & 0.26 & 1.21 & 0.21 & 0.24 & 1.67 & 0.14 & 0.13 & 1.05 & 0.13 \\
\hline
\end{tabular}

${ }^{1} \mathrm{ET}_{0}$ values, calculated using a modified Penman-evapotranspiration method, were obtained from High Plains Regional Climate Center (2012). Data from the Kearney station were used for both study sites. ET is similar to potential evapotranspiration (PET) but is calculated using a different formula with different input data.

\section{Summary}

The Platte River is a vital natural resource for the people, plants, and animals of Nebraska. The Platte River valley and waters are important as habitat for endangered species and migratory birds and as a source of water for irrigation and municipal supply. Decades of changes in water management and land use have led to noteworthy visual changes in the active river channel and adjacent wet meadows. Channel sandbars have developed into forested islands and decreased the wetted channel area substantially from historical conditions. The trees and other vegetation that now dominate these islands have become a concern to water managers because of the presumption that their water consumption is depleting the groundwater supplies needed for irrigation. A study in 2002-05 evaluated the water use of riparian woodlands dominated by cottonwood trees, finding that water use was mainly regulated below maximum predicted levels and was most strongly affected by humidity and water availability.

An important gap in understanding riparian evapotranspiration (ET) along the Platte River is how ET by riparian woodlands compares to that of riparian grasslands. This question is especially relevant in the context of ET salvage, a concept in which less beneficial plant communities (such as unmanaged riparian woodlands) are replaced with alternative plant communities that may provide more direct benefits (such as might be attributed to riparian grasslands), while simultaneously increasing water availability for other purposes. A comparative study was launched to directly compare ET measured using consistent methods at an existing riparian woodland site near Odessa, Nebraska, and a grazed grassland site located along the central Platte River near Elm Creek, Nebr.

Measurement of the ET of two riparian plant communities within the central Platte River valley, Nebr., was made using the eddy-covariance method, and using the equipment, methods, and one of the study locations of the 2002-05 study.

Before the study, the micrometeorological equipment was checked and recalibrated by manufacturers. However, the annual energy balance ratio (EBR) at the grassland site for the first 2 years of the study averaged 0.564 , much lower than the value of 0.932 from the woodland-site data and low enough to raise concerns about the quality of the turbulent flux data. The deployment of an infrared gas analyzer (IGA) in May 2011 improved the EBR at the grassland site, confirming that the krypton hygrometer had malfunctioned. As a result, all prior latent-heat flux values at the grassland site were considered 
unreliable and were therefore discarded. Latent-heat fluxes for the entire study period at the grassland site were subsequently estimated as the residual of the energy balance equation after subtracting the sensible-heat flux from the available energy in the system. Several steps were taken to validate the use of these calculations. First, the energy-balance approach was applied to the data from the woodland site to provide a comparison between measured and estimated ET rates. For all 3 years of the study the annual sum of the calculated ET values was within 3 percent of the measured ET total. Based upon this validation estimated 30-minute ET values for the entire study period were generated for the grassland site.

The installation of the infrared gas analyzer during the summer of 2011 allowed for 214 days of comparison between the estimated ET values at the grassland site and direct ET measurements. The estimated ET for the period of comparison was 451 millimeters (mm), compared to a total measured ET of $452 \mathrm{~mm}$.

The lack of energy balance closure observed at the grassland site does raise some concerns with the estimated ET. The assumption made in data processing during the 2002-05 study was that the measured available energy was overestimated, and it was therefore scaled down to achieve closure. The contrasting assumption would be that the turbulent energy fluxes were underestimated and should be higher. To delimit the measurement error, ET also was calculated for both sites on a daily basis by forcing an energy-balance closure. This value was used as the upper limit of possible ET, the measured and gap-filled values represent the lower limit of possible ET, and the mean of the two limiting values was used and reported as the best estimate for the ET during the study.

Several steps were taken to confirm the quality of the eddy-covariance ET data collected during the study. One method was the comparison, as an EBR, of the eddy-covariance energy flux to the radiation energy flux measured by a net radiometer and a soil-heat-flux plate. Typical EBR values range from 0.7 to 1.0 . At the woodland site the measured 3 -year average annual EBR of 0.923 was considered an indication that high confidence could be placed in the eddycovariance flux data. Late in the study a second water-vaporflux sensor was installed at the sites, providing a means of direct comparison of ET using slightly different technology. For 101 days of comparison at the woodland site the new IGA sensor measured 102 percent of the ET measured by the longterm equipment, with a median daily result of 101 percent of the original sensor during 49 days when ET exceeded $1 \mathrm{~mm}$ per day, providing additional confidence in the reliability of long-term ET measurements at the woodland site.

Overall, the riparian grassland site was characterized by annual ET totals that were 90 percent of the annual ET measured at the woodland site, with averages of $653 \mathrm{~mm}$ and $726 \mathrm{~mm}$, respectively.
Monthly ET results revealed seasonal patterns differing between the two vegetation communities. There was no significant intersite difference in the nongrowing season (November-March) mean monthly ET of $10.4 \mathrm{~mm}(p=0.08)$. During the transition seasons of spring (April-May) and fall (September-October), ET averaged $58.7 \mathrm{~mm} /$ month overall, with the grassland site $(60.3 \mathrm{~mm} / \mathrm{month})$ experiencing slightly higher (but not significantly different) ET than the woodland site $(57.0 \mathrm{~mm} / \mathrm{month})(p=0.11)$. For summer's peak growing months (June-August), ET averaged $134 \mathrm{~mm} /$ month overall, with ET at the woodland site eclipsing the grassland site with approximately $25.1 \mathrm{~mm} /$ month, or 21 percent, more ET $(p=0.0003)$. As with the daily totals, peak monthly totals were always measured during the month of July and were higher at the woodland site than at the grassland site, with peak ET of $191 \mathrm{~mm}$ and $140 \mathrm{~mm}$, respectively. The difference in the observed seasonal pattern in ET is likely a result of the plant community being monitored at each site. The cool-season grasses at the grassland site begin seasonal growth many weeks before the leaves develop on the woodland trees, and after a possible dormant period in the heat of summer the grasses continue to grow into the fall as the trees withdraw resources and begin to drop their leaves. These growth pattern differences help to explain the observed ET patterns, with the riparian grassland having ET rates similar to the riparian woodland during the spring and fall but lower ET rates during the summer. In addition, grazing at the grassland site may have resulted in reduced ET during the summer months and extending ET later into the season as the grasses attempted to recover from the grazing disturbance.

Climatic disparities provided another important explanation for ET differences between the sites. Although the two sites were nearby one another (18.8 km apart), a few climatic drivers of ET (such as vapor-pressure deficit, insolation, and air temperature) were significantly greater at the woodland site during the study $(p<0.03)$.

Annual precipitation for the study period of 2008-09 and 2011 was near to above normal at both sites. Thirty-year average annual precipitation at the woodland site for 1981-2010 was $640 \mathrm{~mm}$, whereas the grassland site averaged $636 \mathrm{~mm}$ of annual precipitation (National Climatic Data Center, 2012). Observed precipitation ranged from 602 to $836 \mathrm{~mm}$ at the woodland site, and from 580 to $989 \mathrm{~mm}$ at the grassland site. The wet year at both sites was 2008, which was driven by much-above-average monthly precipitation in May and October. The regionally wet month of May 2008 caused flooding along the Platte River that caused short-term overbank flow through parts of both study sites.

The annual water balance was calculated for each site and indicated that the predominant factors in the water balance at both sites are ET and precipitation. The sites annual water balance calculations documented a similar pattern and magnitude in the annual groundwater interaction. During 2008 both sites 
experienced a surplus of precipitation compared to ET and average precipitation, leading to a net groundwater recharge of 124 and $322 \mathrm{~mm}$ at the woodland and grassland sites, respectively. There was a deficit in precipitation compared to ET at the both sites in 2009 and 2011, leading to a net groundwater use of greater than $140 \mathrm{~mm}$ per year at the woodland site and greater than $55 \mathrm{~mm}$ per year at the grassland site, confirming that the determination of annual groundwater use or recharge depends predominantly on the relation between the ET and precipitation in these riparian areas with shallow soil layers above the groundwater table.

Monitoring in the 2002-05 study provided four additional annual-water balances dating back to 2002 for comparison with the study period at the woodland site. Perhaps most striking in this comparison was the 25-percent increase in annual ET for 2008-09 and 2011 despite precipitation totals and potential ET rates that were within the range of those monitored in 2002-05. This increase in ET was responsible for a corresponding increase in groundwater usage, resulting in groundwater discharge in 2 of 3 years. There are likely two primary reasons for the increase in ET. First, the woodland vegetation health likely was improved in 2008-09 and 2011 as compared to the drought-affected years of 2002-05, as evidenced by the increases in peak leaf area index values. In addition, groundwater levels were higher in 2008-09 and 2011 than they were in 2002-05, reducing the effects of water limitation on the plants.

Daily ET was simulated for the study period using the monthly crop coefficients $\left(k_{\mathrm{c}}\right)$ developed for the woodland site for the 2002-05 study. Overall the simulated ET was lower than measured ET for the entire growing season and only averaged 65 percent of annual measured ET for the 3 years of 2008-09 and 2011. Simulated monthly ET values were especially low during the peak ET months of June-August. New monthly crop coefficients incorporating all 7 years of record were calculated for the woodland site, producing nearly identical $k_{\mathrm{c}}$ values for October through May and higher $k_{\mathrm{c}}$ values for June through September. Monthly crop coefficients also were developed for riparian grasslands using the ET values from the grassland site. The $k_{\mathrm{c}}$ values developed for the grassland site were similar to the $k_{\mathrm{c}}$ values from the woodland site during the same time period.

There was considerable difference in the average monthly measured ET for the two separate study periods at the woodland site. One possible explanation for this difference is the lower soil-water content in 2002-05 that may have restricted ET rates and led to degraded plant health. This suggests that soil-moisture stress is an important factor to consider when using crop coefficients to simulate ET in areas without natural or managed consistency in soil moisture, even in riparian areas or other regions with a shallow water table. The differences also reveal some of the limitations associated with using crop coefficients to represent diverse plant communities.

\section{References Cited}

Allen, R.G., Pereira, L.S., Raes, Dirk, and Smith, Martin, 1998, Crop evapotranspiration-Guidelines for computing crop requirements: Rome, Italy, United Nations Food and Agriculture Organization, Irrigation and Drainage Paper no. $56,300 \mathrm{p}$.

Allen, R.G., Pereira, L.S., Smith, M., Raes, D., and Wright, J.L., 2005, FAO-56 dual crop coefficient method for estimating evaporation from soil and application extensions: Journal of Irrigation and Drainage Engineering, v. 131, no. 1, p. $2-13$.

Bremer, D.J., Auen, L.M., Ham, J.M., and Owensby, C.E., 2001, Evapotranspiration in a prairie ecosystem-Effects of grazing by cattle: Agronomy Journal, v. 93, no. 2, p. 338-348.

Center for Advanced Land Management Information Technologies, 2007, Delineation of 2005 land use patterns for the State of Nebraska Department of Natural Resources: Lincoln, Nebr., CALMIT, 80 p., accessed February 8, 2013, at http://snr.unl.edu/data/download/geographygis/2005_ NE_landuse_finalreport.pdf.

Central Nebraska Public Power and Irrigation District, 2013, Operations of the Central District: Holdrege, Nebraska, The Central Nebraska Public Power and Irrigation District, accessed September 26, 2013, at http://www.cnppid.com/ Operations.htm.

Dick, E.N., 1975, Conquering the Great American Desert: Nebraska: Lincoln, Nebr., Nebraska State Historical Society, $456 \mathrm{p}$.

Gu, Jiujing, Smith, E.A., and Merritt, J.D., 1999, Testing energy balance closure with GOES-retrieved net radiation and in situ measured eddy correlation fluxes in BOREAS: Journal of Geophysical Research-Atmospheres, v. 104 (D22), p. 27, 881-93.

Healy, R.W., and Cook, P.G., 2002, Using groundwater levels to estimate recharge: Hydrogeology Journal, v. 10, p. 91-109.

High Plains Regional Climate Center, 2012, National Weather Service surface observations and automated weather data network data: Lincoln, Nebr., University of Nebraska, digital data, accessed October 23, 2012, at http://www.hprcc. unl.edu.

Jensen, M.E., Wright, J.L., and Pratt, B.J., 1971, Estimating soil moisture depletion from climate, crop and soil data: Transactions of the American Society of Agricultural Engineers, v. 14 , no. 5, p. 954-959. 
Johnson, W.C., and Boettcher, S.E., 2000, The presettlement Platte: wooded or prairie river?: Great Plains Research, v. 10, p. 39-68.

Knyazikhin, Y., Glassy, J., Privette, J.L., Tian, Y., Lotsch, J., Zhang, Y., Wang, Y., Morisette, J.T., Votava, P., Myneni, R.B., Nemani, R.R., and Running, S.W., 1999, MODIS leaf area index (LAI) and fraction of photosynthetically active radiation absorbed by vegetation (FPAR) product (MOD15) algorithm theoretical basis document: Greenbelt, Md., National Aeronautics and Space Administration, accessed March 5, 2013, at http://modis.gsfc.nasa.gov/data/atbd/ atbd_mod15.pdf

Landon, M.K., Rus, D.L., Dietsch, B.J., Johnson, M.R., and Eggemeyer, K.D., 2009, Evapotranspiration rates from riparian forests, Platte River, Nebraska, 2002-06: U.S. Geological Survey Scientific Investigations Report 2008-5228, $65 \mathrm{p}$.

Larson, L.W., and Peck, E.L., 1974, Accuracy of precipitation measurements for hydrologic modeling: Water Resources Research, v. 10, no. 4, p.857-863.

Lee, X., Finnigan, J.J., and Paw U, K.T., 2004, Coordinate systems and flux bias error, in Lee, Xuhui, Massman, W.J., and Law, Beverly, eds., Handbook of micrometeorology: New York, Kluwer Academic Publishers, p. 33-66.

National Climatic Data Center, 2012, Climate data online: Asheville, N. Car., National Oceanic and Atmospheric Administration, digital data, accessed July 12, 2012, at http://www.ncdc.noaa.gov/cdo-web/search.

Nebraska Department of Natural Resources, 2004, Fully appropriated basin order, accessed September 26, 2013, at http://dnr.ne.gov/IWM/Notice/Order_of_Final_ Determination_9-30-2004.pdf.

Norling, B.S., Anderson, S.H., and Hubert, W.A., 1992, Roost sites used by sandhill crane staging along the Platte River, Nebraska: Great Basin Naturalist, v. 52, no. 3, p. 253-261.
Priestley, C.H.B., and Taylor, R.J., 1972, On the assessment of surface heat flux and evaporation using large-scale parameters: Monthly Weather Review, v. 100, p. 81-92.

Schuepp, P.H., Leclerc, M.Y., Macpherson, J.I., and Desjardins, R.L., 1990, Footprint prediction of scalar fluxes from analytical solutions of the diffusion equation: BoundaryLayer Meteorology, v. 50, p. 335-373.

TIBCO Software, Inc., 2008, TIBCO Spotfire S+ 8.1 for Windows: Somerville, Mass., TIBCO Software Inc., version 8.1.

U.S. Department of Agriculture, 2013, The PLANTS database: Greensboro, N. C., Natural Resources Conservation Service, accessed January 17, 2013, at http://plants.usda.gov.

U.S. Fish and Wildlife Service, 2013, Environmental conservation online system: Fort Collins, Colo., U.S. Fish and Wildlife Service, accessed September 26, 2013, at http:// ecos.fws.gov/tess_public/pub/stateListingAndOccurrenceInd ividual.jsp? state $=N E$.

U.S. Geological Survey, 2013, National Water Information System data available on the World Wide Web (USGS Water Data for the Nation), accessed March 13, 2013, at http://waterdata.usgs.gov/nwis/.

White, W.N., 1932, A method of estimating ground-water supplies based on discharge by plants and evaporation from soil-Results of investigations in Escalante Valley, Utah: U.S. Geological Survey Water-Supply Paper 659-A, 209 p.

Wilson, K., Goldstein, A., Falge, E., Aubinet, M., Baldocchi, D., Berbigier, P., Bernhofer, C., Ceulemans, R., Dolman, H., Field, C., Grelle, A., Ibrom, A., Law, B.E., Kowalski, A., Meyers, T., Moncrieff, J., Monson, R., Oechel, W., Tenhunen, J., Valentini, R., and Verma, S., 2002, Energy balance closure at FLUXNET sites: Agricultural and Forest Meteorology, v. 112, p. 223-243. 
Appendixes 1-2 
Appendix 1. Daily values of micrometeorological variables from riparian woodland study site near Odessa, Nebraska, January 1, 2008, to December 31, 2009, and January 1, 2011, to December 31, 2011.

(Excel spreadsheet, appendix1.xlsx, available at http://pubs.usgs.gov/sir/2013/5203/)

\section{Appendix 2. Daily values of micrometeorological variables from riparian grassland study site near Elm Creek, Nebraska, January 1, 2008, to December 31, 2009, and January 1, 2011, to December 31, 2011.}

(Excel spreadsheet, appendix2.xlsx, available at http://pubs.usgs.gov/sir/2013/5203/) 
Publishing support provided by: Rolla and West Trenton Publishing Service Centers

For more information concerning this publication, contact: Director, Nebraska Water Science Center

U.S. Geological Survey

5231 South 19th Street

Lincoln, NE 68512-1271

(402) 328-4100

Or visit the Nebraska Water Science Center Web site at: http://ne.water.usgs.gov/ 
